\title{
The Conflicted State and Agrarian Transformation in Pink Tide Venezuela
}

\author{
LAURA J. ENRÍQUEZ AND SIMEON J. NEWMAN
}

\begin{abstract}
Can radical political-economic transformation be achieved by electoral regimes that have not thoroughly reconstructed the state? Contemporary Venezuela offers an optimal venue for examining this question. The Chavista movement did not replace the previous state: instead, its leaders attempted to reform existing state entities and establish new ones in pursuit of its transformation agenda. It has also used its oil wealth to support cooperatively-oriented economic activity, without necessarily fundamentally altering the property structure. Thus, the social change-oriented political economy exists alongside the traditional one. Focusing on agrarian transformation, we examine ethnographically how these factors have impacted the state's capacity to attain its goal of national food sovereignty. We find that the state's ability to accomplish this objective has been compromised by lack of agency-level capacity, inter-agency conflict and the persistence of the previously-extant agrarian property structure. These dynamics have influenced the state to shift from its initial objective of food sovereignty to a policy of nationalist food security.
\end{abstract}

Keywords: pink tide states, state capacity, development, food sovereignty, agrarian reform

\begin{abstract}
What is the State going to develop? The Venezuelan revolution is not the Soviet one, in which, in the midst of an enormous crisis, the armed workers assaulted the power structure, destroyed the old State and constructed a new one. Nor is it the Cuban revolution, in which an armed movement assaulted the structure of power and constructed a new one. Here, it came to be through an electoral process. The structure of the State is basically the same [as it was before] ... A revolution will have a difficult time successfully moving forward with a State with these characteristics.
\end{abstract}

Alí Rodríguez Araque ${ }^{1}$

Laura J. Enríquez (corresponding author), Department of Sociology, 410 Barrows Hall, University of California, Berkeley, CA, 94720, USA. E-mail: enriquez@berkeley.edu. Simeon J. Newman, Department of Sociology, University of Michigan, 3001 LSA Building, 500 S. State Street, Ann Arbor, MI 48109, USA. E-mail: simnew@ umich.edu

We would like to thank the numerous individuals who gave their time to be interviewed for this paper, including many government officials, representatives of non-governmental organizations and farmers. Miguel Angel Núñez and César Alejandro González deserve special recognition for their support at various stages of this project. We are also grateful for the comments provided by the peer reviewers of this paper. Financial assistance was provided by a Faculty Research Grant awarded by the Committee on Research of the University of California at Berkeley, which made the fieldwork for this paper possible. The opinions expressed herein are those of the authors, however, and should not be attributed to any of the above-mentioned persons or institutions.

1 Cited in Da Corte $(2014,2)$. 
... the problem of food security means that they cannot leave behind, just like that, production as it is now structured. But, when [will it be possible to put in place] the other model?

Government official, Portuguesa ${ }^{2}$

\section{INTRODUCTION}

When Hugo Chávez was elected president of Venezuela in late 1998, many interpreted it as the dawn of a new era in Latin American politics. After more than a decade of neo-liberal hegemony in policy-making throughout most of the region, his rise to power suggested that an alternative was possible. Indeed, his election was followed in short order by electoral victories by presidential candidates of the left and centre-left in numerous Latin American countries. However, even before this 'Pink Tide' gained strength, Chávez's government succeeded in reorienting politics and laying out a very distinct agenda for Venezuela's 'Fifth Republic'. And, by 2005, that agenda had been further radicalized, as evidenced by Chávez's call for a 'socialism of the twenty-first century'.

Although it espouses socialist nomenclature, the Chavista movement came to power by means dissimilar from most socialist regimes. In Russia, China and Cuba, an alternative pole of popular political power replaced the old state through armed struggle. In contrast, in Venezuela, discontent coalesced in a political opening, followed by the election of the popular radical Hugo Chávez. And the Chávez-initiated project of social, political and economic transformation, known as el proceso, has been of a different nature. Though it has explicitly sought profound social change, Chavismo, as embodied in both the movement and its leadership, did not replace the old state. Instead, it transformed numerous existing agencies and augmented the old state structure with new agencies - resulting in a dual-institutional structure - in pursuit of its novel agenda. ${ }^{3}$ Despite recognition of the centrality of the state and of its institutional duality, scholars of el proceso have tended to focus their attention elsewhere. They have examined the nature of the political leadership, divergences within it and dynamics in the popular movements to explain the course of social change in contemporary Venezuela. ${ }^{4}$ Consequently, a key question has also gone unanswered: to what extent has the Venezuelan state been capable of pursuing its agenda in the absence of thoroughgoing state renovation; that is, given the electoral nature of the regime and the embeddedness of el proceso's agencies amidst those of the old state?

The ramifications of this question are profound, both for the future of Venezuela and for a social-scientific understanding of such a dualistic state. Evaluating the capability of the Venezuelan state to accomplish its goals is important if one is to assess the possible differences between a Venezuela with Chávez at its head versus one without. Venezuela's political future may have just as much to do with its institutional arrangement as with political personages. Moreover, despite sustained interest in researching and theorizing the relationship between states and societies, we continue to lack an adequate understanding of how state capacity fares

Interview, 28 June 2012.

As Ellner $(2008,143)$ points out, 'the Chavista strategy of creating parallel structures implies tolerance of and, in the case of the public sphere (such as schools and hospitals), budgetary allocations for the old structures ... The approach contrasts with the traditional revolutionary concept of an abrupt and thorough break with the past.'

4 See, for example, Cannon (2009), Ellner (2008) and Fernandes (2010). This literature will be further discussed below. 
when 'deliberate attempts at reform or reorganization are made within solidly established state structures' (Evans et al. 1985, 361). This latter conundrum aptly describes the Venezuelan case, due to the reconfiguration of numerous state agencies during Chávez's tenure.

There have been a variety of implications of this circuitous means of pursuing social change. One is that, since the state consists of a set of agencies, each of which has a specific history and goals, some of which have been reconfigured and others of which persist in essentially unaltered form, there are myriad possibilities for inter-bureau conflict. Hence, the question becomes: when the state adds new agencies in pursuit of new goals, reconfiguring its 'solidly established state structure', what are the consequences for the state's capacity to pursue its agenda?

In this paper, we analyse these political dynamics through an examination of the state's efforts to transform agrarian production in Portuguesa, one of the country's most agriculturally important states. One might reasonably ask, why study the agrarian state in a nonagrarian country? It is widely known that Venezuela is a petroleum-exporting country that imports much of its food. Venezuela's agricultural sector is crucial for several reasons, at least some of which are all the more pressing due to the regime's electoral nature. First, establishing new agricultural production relations has been a central component of the state's vision for reorganizing society. Second, restructuring of property relations, which is part of the process of change in Venezuela, is a key factor contributing to the tapestry of violence nationwide. The Venezuelan state has accomplished little in terms of reducing crime and insecurity, and this fact was a central plank of the opposition's electoral platform in the 2012 and 2013 presidential contests. Third, the availability and price of food conditions the degree to which the regime can maintain its base of support and pursue its other social change objectives. Deficient national food production fuels already high inflation (another rallying cry of the regime's opposition) and, thereby, impinges upon the legitimacy of the state.

It is difficult to overstate the importance of food for the Venezuelan state. The country experienced food scarcity during an opposition-led economic boycott from late 2002 to early 2003. This made state actors painfully aware of the need to reorganize production such that it would no longer remain in the hands of those who opposed state goals. It was precisely this effort to reorganize production that led to the changes in the food system upon which we have set our analytical sights.

Hence, this paper addresses two specific questions: what role has a lack of state capacity played in the inability to transform agriculture definitively in favour of small- and mediumscale producers? These sectors had been central to the state's vision of the means to achieve food sovereignty, which it conceived of as ensuring local production of culturally relevant food products in sufficient quantity to feed the population. ${ }^{5}$ The answer to this first question effectively contains the answer to our second specific question: Why did the Chávez government shift from a preference for food sovereignty to a preference for food security? ${ }^{6}$ We find that the state's ability to achieve food sovereignty has been compromised by lack of agencylevel capacity, inter-agency conflict and the continuing weight of large-scale private property in the agrarian sector. These dynamics have influenced the state to shift from its initial objective to a policy of nationalist food security.

\footnotetext{
5 Moreover, the common conception of food sovereignty maintains that this local production will be based on sustainable practices and carried out by small- and medium-sized producers. This concept will be discussed further in the subsection entitled 'Three Pillars of Agrarian Policy', both with regard to academic considerations of it and to references to it in official documents.

6 As will be discussed below, the pursuit of food security does not presuppose a central role for small- or medium-scale farmers in this endeavour.
} 
In our examination of these questions, we pursued the following strategy. For the summer of $2012,{ }^{7}$ we undertook fieldwork in the State of Portuguesa, during which we interviewed state functionaries from each of the agencies involved in agrarian policy-making and implementation. We visited several reformed sector farms (Fundos Zamoranos and Socialist Production Units, or UPSs), interviewed their leaders, toured their grounds and observed their leaders' interactions with state functionaries. ${ }^{8}$ In addition, we interviewed leaders of peasant and large-grower organizations, individuals in the state-run food processing industry, and local and national politicians; and we observed meetings in which government officials met with distinct sectors of the rural population to discuss agrarian policy and its implementation. All told, we interviewed 54 individuals from 28 state and non-state entities (which we supplemented with observational data). We relied upon both purposive and snowball sampling in selecting those interviewed, so as to ensure that we would hear the perspectives of the diverse array of actors in Venezuela's contemporary agrarian sector. Moreover, we obtained quantitative data on the landholding structure, agricultural production and state lending practices, and other primary source materials pertaining to our research questions. Finally, we revisited the field in 2014 and conducted additional interviews.

The discussion that follows begins with a review of the relevant literature. We then provide a sketch of Venezuelan politics prior to Chávez's election, and of his agenda upon assuming office, focusing especially on the goal of agrarian transformation that became central to it. We describe the modifications of the state structure intended to make agrarian transformation possible, and examine how this transformed structure related to reformed sector farms. Specifically, we analyse the capacity of the state's various agencies to implement the intended transformation, instances in which these agencies cooperated and instances in which they came into conflict with one another. We are aware that additional factors besides the structure and capacity of the state and its agencies have contributed to determining the course of change in Venezuela's countryside, including the relative strength of its agrarian elite and the relative weakness of its peasant movement. However, our interest in this paper lies in the role of the state in this process. We conclude the paper by discussing the ways in which the Venezuelan state's novel configuration has limited its capacity to accomplish its agrarian transformation goals.

\section{THE STATE, DEVELOPMENT AND RADICAL SOCIAL CHANGE}

Development initiatives that seek radical social change require a state that has specific characteristics. First, it must be capable of shifting its support from the sectors of society that had been prioritized in policy-making in the past. Second, it must be capable of adequately supporting its political-economic transformation intentions and initiatives. Scholars from several schools of thought have looked at these issues through the study of empirical cases, as well as through a more theoretical lens.

The empirically-oriented development literature maintains that state capacity - variously defined - is essential for affecting development outcomes. Evans (1995) argues that bureaucratic-cultural characteristics within state agencies are key in this sense: development outcomes are produced by the rational organization of intra-bureau dynamics, or

This period of fieldwork forms part of a larger, ongoing research project that is analysing intra-state dynamics and their impact on the process of change in several distinct regions of Venezuela. See also Enríquez (2013).

8 We visited three of the six Fundos Zamoranos in the State of Portuguesa, one of the state's agricultural UPSs, and one food-processing UPS. For a Glossary of Acronyms, see Appendix A. 
'Weberianness' (see also Evans and Rauch 1999) - as well as by their autonomy from elites. Amsden (2001) finds that 'late-industrializing' countries were most successful when their states not only maintained repressive labour policies, but also successfully cajoled domestic capital into investing in what they predicted would be the most important industries. In keeping with Mann's $(1984,192)$ assertion that the first condition giving rise to state capacity is a 'division of labour between the state's main activities', Chibber $(2002,984)$ notes that development outcomes depend on a well-organized division of labour between state agencies: it is 'at the level of the bureau, not the bureaucrat' that development goals succeed or fail. This division of labour must ensure that agencies do not come into conflict with one another, and must provide an authoritative planning agency with accurate information to these ends. In the absence of such coordination, each ministry may become 'a state within a state', 'contributing to the fragmentation of the state' (Chibber 2002, 964, 985).

Yet, unlike the classical developmental states that Evans, Amsden and Chibber write of, in which growth, specialization and/or diversification of a capitalist economy is the objective, Venezuela has sought social transformation as part of its political-economic agenda. This entails redistributive efforts, as the new development priorities move beyond the promotion of growth to also include equity (Fagen et al. 1986, 17). Nonetheless, when states pursue income redistribution, Evans and Rueschemeyer $(1985,53)$ argue, 'effective bureaucratic organization as well as the issue of competence and factual knowledge required for intervention are perhaps nowhere more put to the test'.

There is a relative paucity of both theoretical and empirical research on such redistributive development initiatives. Classical Marxist theorists did not anticipate an ongoing division of power between revolutionary and status quo-oriented state agencies, but instead insisted that the pre-revolutionary state was to be smashed in order to sever ties with old elites and erect a new state capable of pursuing popularly-oriented political, cultural and economic change. In his discussions of the process of revolutionary transformation, in which 'dual power' plays a brief but critical role, Lenin (1975b [1917], 297) stresses the importance of 'transferring the entire state power to the Soviets' - the revolutionary institutions that constituted a 'direct initiative of the people from below' (see also Lenin 1975a [1917]). Trotsky did suggest that 'dual power' might be prolonged, as the revolutionaries succeeded in attaining control over some governmental organizations while moderates continued to control others (Trotsky 1957 [1932]). ${ }^{9}$ However, given the situation of armed struggle he and Lenin were analysing, Trotsky did not envision a leftist government permitting prerevolutionary institutions and their constituencies in society to maintain power indefinitely. Subsequently, Tilly (1973) argued that the concept of dual power - which he rechristened as 'multiple sovereignty' - is crucial to the study of the politics of revolution. But there is little research on institution-building, the determinants of policy and the problem of development in such contexts.

Several neo-Marxist scholars discuss aspects of the state that are relevant for development where a panorama such as this prevails. As opposed to the neo-Weberians, who define states in formal-organizational terms, Poulantzas sees the state as the 'material condensation of . . . a relationship among classes' and their constituent parts (1978, 128; emphasized in the original). The capitalist state serves to simultaneously organize fractions of the dominant class and disorganize the popular classes $(1973,188-9,229-40,299-301 ; 1978,127,136,140,148) .{ }^{10}$

\footnotetext{
9 For a review of the evolution of the concept of 'dual power', see Rockefeller (2007).

10 Thus, for Poulantzas (see esp. 1969), the important issue is not who occupies positions of state power but, rather, what the state does vis-à-vis classes.
} 
Yet, because of its substantive organizational role, the capitalist state harbours myriad internal contradictions (1978, part two passim). That is, for Poulantzas, problems with what Mann calls the inter-agency 'division of labour' stem from contradictions between class fractions. Several other neo-Marxist scholars have pointed to contradictions within the state and elaborated their implications. Abrams (1988) argues that the state is a series of disjointed agencies and that it is only the 'state idea' - the way people think about the state - that is responsible for the notion that the state is a single entity at all. Similarly, Corrigan and Sayer (1985) argue that the English state simultaneously helped unify the disparate dominant class fractions and mould the morality of the working class to incorporate it into the bourgeois nation, thereby changing popular culture such that the state became understood as a unified - and legitimate - organization (1985, 141, 191 and passim). Still, although all of these authors acknowledge intra-state contradictions, Poulantzas' argument for their significance is quite different. For him, 'contradictions between, and within, the various state branches and apparatuses' determine 'the current policy of the State' $(1978,134) .{ }^{11}$

Yet, despite the fact that Poulantzas theorizes the contradictions internal to the state and how these affect policy, and the fact that he discusses alternatives to the smash-the-state formula for the transition to socialism, he does not adequately theorize configurations in which portions of the state pursue the interests of the dominated classes. ${ }^{12}$ Thus, even though he advocates a gradual transition to socialism (1978, 252-61), he does not speak to its implications. That is, he does not address the relationship between portions of the state beholden to the interests of the hitherto dominant class and portions that pursue the interests of the hitherto dominated classes, much less the relationship between agencies in the latter category that correspond to interests of fractions of the dominated classes. ${ }^{13}$

Drawing from Poulantzas, Jessop (1982) conceptualizes the state in more general terms and, thus, allows for myriad configurations of the state vis-à-vis classes and their fractions. He argues that the state should be understood as an institution that affects classes and expresses a balance of force between them. But he also suggests that, rather than attempt to theorize the capitalist state, our analytical sights should be set on whether a given state 'creates, maintains, or restores the conditions required for capital accumulation' (1982, 221). This points to two important implications: (i) 'the relative dominance of particular departments or ministries ... can underwrite the hegemony of a given class fraction'; but also (ii) 'state structures can undermine the pursuit of a project favourable to another class or class fraction' (1982, 232).

Intervention as such, of course, requires interventionist state structures. In the wake of the weakening of state institutions that resulted from neo-liberal restructuring in much of Latin America during the 1980s and 1990s, Borón (2008) makes the case that one of the first steps that will be necessary to pursue socialist development will be a 'refounding' or reconstruction

\footnotetext{
11 Not only is state policy important for overt agenda setting, but also because the state shapes society by 'apportioning-distributing' individuals into classes (Poulantzas 1978, 75).

${ }_{12}$ In capitalist social formations, he argues, the norm is that such configurations do not obtain (Poulantzas 1978, 138-9). Unlike the situation for the dominant classes - for whom state 'apparatuses or branches ... crystallize a power that is peculiar to these classes and fractions' - Poulantzas $(1978,142)$ argues that the dominated classes do not enjoy state apparatuses or branches; instead, they 'exist . . . in the State ... in the form of centres of opposition to the power of the dominant class'.

13 Indeed, after discussing his preference for the preservation of representative democracy along with the institution of direct democracy in the transition to socialism (Poulantzas 1978, 254-60), Poulantzas raises the question of how these two forms would work in tandem. But his response is that 'the answer to such questions does not yet exist' $(1978,265)$.
} 
of the state so that it is equipped to take on the tasks that will be required of it. ${ }^{14}$ Although he outlines the principles upon which the socialist development of the twenty-first century should be based, and some of the policies that it should promote, Borón does not speak to the issue of how pre-existing and/or new state agencies would interface to facilitate or obstruct this effort.

Coraggio (1986) does soberly note that socialist states established after the mid-twentieth century have often been built upon the remains of pre-revolutionary ones. This creates the very real possibility that the state structure will not be in sync with a radical politicaleconomic agenda. Hence, the division of labour between distinct parts of the state may not coincide with policy-making geared towards transformation. Moreover, Coraggio (1986, 151, 153) posits that each part of the state will 'attempt ... to respond to the political directives of the revolutionary project, interpreting these according to their sectoral or institutional vision'. This can lead to institutional fragmentation, if not outright contradictory policy-making.

These possibilities and tensions are multiplied exponentially when radically-oriented regimes come to power through elections - wherein the rules of the political game have not been dramatically changed - and decide to retain the old state apparatus and establish a division of power between 'revolutionary' and 'old regime' state structures. In the case of Venezuela, as Nelson (2013) points out, the ratification of a new constitution in 1999 provided the legal architecture for a shift in priorities within the state structure. But divergent institutional interests, which had been present in the 1990s yet deepened sharply in the 2000s, were evident in the state's distinct 'institutional apparatuses' (Nelson 2013, 176). Consequently, the potential for fragmentation and 'dual power' was extended indefinitely, raising questions about the relationships between the state's two institutional structures, the dynamics within each, and those between each structure and the portions of society to which they orient.

Of foremost importance for this kind of state - prior to, but also inherently related to, the redistribution of wealth - is the need to ensure availability of the population's basic necessities. For Thomas (1974), the 'First "Iron Law" of Transformation' for regimes undertaking a transition to socialism is to have control over production of what the population needs to consume. While Thomas argues that such regimes must find a way for this production to occur within national boundaries in order to circumvent interference by foreign states that oppose such change, the 'Iron Law' principle is also applicable to domestic opposition. Regardless of the location of opposing forces, states in transition to socialism must ensure that the production of necessities - of which food is the most basic - is controlled by those who are 'with the project'. Thus, to accomplish political-economic transformation, the state en route to socialism must not merely redistribute wealth. It must also augment production among sympathetic sectors without incurring greater decreases in productivity among the propertied classes whose activity has hitherto contributed an essential part of domestic production. This is a formidable task, since state-led reform of the property structure has often been associated with declines in production (cf. Przeworski 1991).

In confronting this challenge, the Venezuelan state has had unique advantages that might allow it to 'cheat' on the typical inverse association between reform and productivity. First, the Venezuelan state has historically imported much of its food. Therefore, the country could conceivably suffer declines in production if they were merely a temporary result of the implementation of reform measures. Second, with some of the largest petroleum reserves in the world, the Venezuelan state has had abundant resources to employ during the reform

14 Beasley-Murray et al. (2010) also argue for the need to refound the Latin American state in their discussion of the pink tide regimes that have emerged in the region. 
process. ${ }^{15}$ As Table 1 shows, during the years between 2001 and 2011, Venezuela relied on importation of between 22.6 and 99.7 per cent of its rice, most of its corn and about half of its sorghum (which is used in animal feed). ${ }^{16}$ The country's oil wealth has also enabled the state to finance a great deal of the kind of production that it seeks to promote. With such wealth, the Venezuelan state may be said to face the best of all possible scenarios for pursuing an electoral/evolutionary path towards socialism. Yet, even petroleum experiences downturns in its value in the international economy. The potential negative consequences of such downturns for Venezuela were seen in the country's economic crisis of the 1980s, and they have certainly contributed to the economic difficulties facing Venezuela in the second decade of the twenty-first century. ${ }^{17}$ Nonetheless, for a state that relies so heavily on one particular kind of export product, Venezuela's petroleum reserves provide it with significantly greater opportunities than most primary-product exporting nations. ${ }^{18}$

Venezuela's immense oil wealth has also meant that active intervention of the state in the economy is not new there. Starting in the late 1930s, the Venezuelan state positioned itself as the uncontested representative of the nation by selling the country's vast petroleum reserves and distributing the spoils across society, thereby 'sowing' the oil (Coronil 1997, 105, 134; see also Karl 1997; Di John 2009). In addition, the Petroleum Law of 1943 and the nationalization of the country's oil production in 1976 (Coronil 1997, 55) fundamentally altered the relationship between the state, the economy and the nation. The latter event also coincided with a boom in the international price for the commodity, bringing great resources into the state's coffers (Di John 2009, 22-3).

The rentier-state literature has argued that when states' revenues derive from petroleum, they become incapable of changing development paths (Karl 1997). This is because petroleum wealth: (i) spawns 'social forces with strong vested interests in perpetuating oil-led development' - that is, 'a client private sector, middle class, and labor force emerge whose raison d'être is to sustain the existing [development] model'; (ii) encourages rent seeking and corruption among state officials; and (iii) produces state institutions that 'lack the authority and corporate cohesiveness necessary to exercise effective capacity' (Karl 1997, 54, 57, 58; cf. Mahdavy 1970, 447, 463, 467; Yates 1996, 21-2, 29, 30, 35). Together, Karl (1997, 67 and passim) argues, these factors lock petro-states into their development trajectories. Yet, as Di John $(2009,133-44)$ observes, such categorical conclusions fail to account for the fact that development initiatives may be more or less successful, despite such limiting conditions, depending on the prevailing polity configuration and the development objective sought. Moreover, several of the Chávez government's initiatives have altered considerably the first set of domestic-political mechanisms that Karl points to as reasons for development path dependency: the regime distanced itself from the private sector with a series of (re)nationalizations

15 Venezuela's oil wealth, and the way in which it has affected the country's political economy, also influenced our decision to focus on the state - rather than, for example, on the balance of class forces in the countryside in explaining policy preferences. That is, due largely to the influence of oil, since the middle of the twentieth century the weight of agricultural elites and agricultural issues, in general, vis-à-vis national politics has steadily declined (Coronil 1997, 83, 87, 185).

16 Gutiérrez Socorro (2013) provides data describing the significant increase in food imports overall. As noted in footnote 22 below, discussion of this trajectory and its causes - while an important topic - is not the focus of this paper.

17 On the economic downturn of the 1980s and its social consequences, see Buxton (2003); and on the present decade, see Nardelli et al. (2014).

18 We should note, however, that petro-rentier states are notoriously ineffective at direct taxation, and thus, theoretically, must rely on subsidization rather than fiscal capacity to affect redistribution (Mahdavy 1970, 453; Yates 1996, 33-6; Karl 1997, 58-64; see also Coronil 1997, 77-8 and passim). 


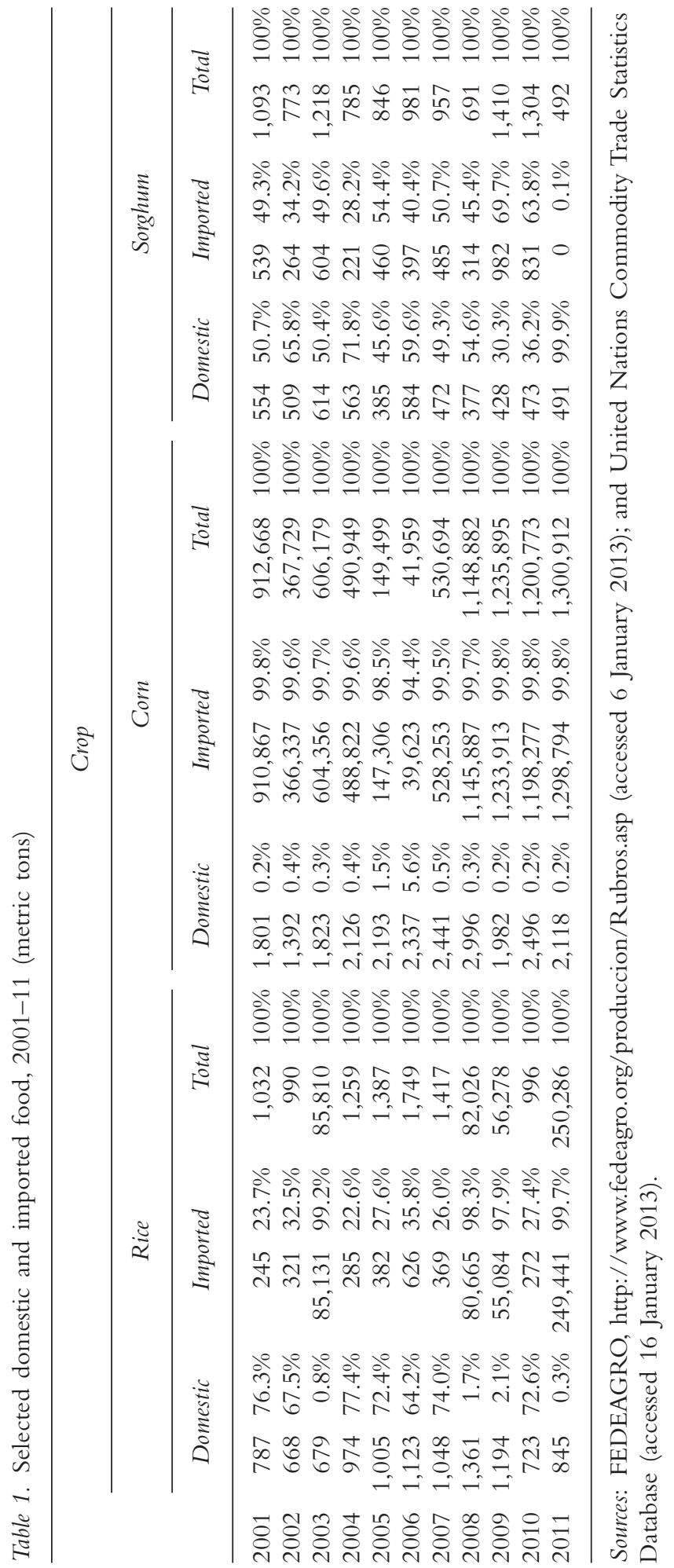


(Ellner 2008, 112-21, 126-27; Ellner 2013, 66-70); progressively alienated much of the middle class and coalesced its main base of support among the hitherto relatively marginalized rural and urban poor (Fernandes 2010; Roberts 2006); and it made inroads into the corporatist power of privileged national oil company employees by firing 18,000 of them (of which a portion were reinstated) after the company's management led a lockout in 2002 in protest against changes to the status quo (Ellner 2008, 159). Although rent seeking and corruption have certainly endured, this interruption of the heretofore 'oil-based social contract' (Karl 1997, 57) suggests that contemporary Venezuelan state institutions may be able to avoid their supposed fate - that is, escape path dependency - and embark on development projects irreducible to mere rent transfer, corruption, dross or spectacle, at least within certain scope parameters.

The rentier-state literature is unanimous that petro-states develop into relatively autonomous and large structures (Mahdavy 1970; Yates 1996; Coronil 1997; Karl 1997). Such a state resembles postcolonial African states that had what Alavi (1972) calls an 'overdeveloped apparatus'. In Africa, this was the result of inheriting a colonial apparatus that had attained 'dominion over all the indigenous social classes in the colony' (Alavi 1972, 61). While its origins were different, the Venezuelan state shares with such states the fact that it 'directly appropriates a very large part of the economic surplus and deploys it in bureaucratically directed economic activity in the name of promoting economic development' (Alavi 1972, 62). ${ }^{19}$ Because of these dynamics, Saul (1974), drawing on Alavi, saw such states as having a 'semi-autonomous role' in determining their actions vis-à-vis society. With autonomy from society, struggles within the state determine the development path that the state will pursue. Saul argues that workers and peasants are likely to suffer as a result.

In the Venezuelan case, however, there are several factors that may allow the peasantry to avoid such an outcome. Beyond the fact of the regime's explicit pro-poor agenda, Venezuela's oil wealth may provide the state with means sufficient to allow at least some agencies to respond favourably to peasant interests, despite the state's relative autonomy. ${ }^{20}$ In an analysis of the Mexican peasantry's engagement with that state, Fox (1992) finds that pressure from below can impel officials in certain agencies to press forward with pro-poor policies, despite opposition from other parts of the state. Also, Wolford $(2010,94)$ found a similar dynamic at play with regard to the Landless Rural Workers' Movement (MST) and the Brazilian state, arguing that, for this reason, the land reform was a 'site of participatory democracy'. Nonetheless, the Mexican and Brazilian peasantries confronted states very different from the dualinstitutional Venezuelan state. In the Venezuelan context, it was unclear the extent to which peasants would fare similarly.

\section{THE VENEZUELAN CASE}

\section{From punto fijo to el proceso}

Although it has had an interventionist state for the past eight decades, Venezuela's institutional dualism has only characterized that state since the Chávez administration. For most of the late

\footnotetext{
19 This has been especially true since, under Chávez, the Venezuelan state 'gained a $60 \%$ controlling stake [in the state oil company], taxes and royalties were significantly increased, drilling rights were reduced ... and investors were denied access to international arbitration of investor-state disputes' (Haslam 2010, 223).

20 This is related, but not limited, to the fact that Venezuela is a 'nature-exporting' country whose revenues are derived primarily by means other than taxing the population (cf. Coronil 1997, 7 and passim).
} 
twentieth century, Venezuela's immense oil wealth underwrote a relatively quiescent political order. During what was known as puntofijismo, the two primary political parties' programmes converged as they alternated in and out of power. Starting in the early 1980s, however, declining oil prices forced the state to curtail public expenditures, precipitating a growth in poverty, unemployment and economic informality (Buxton 2003, 116). In response to the economic turmoil, Venezuelan heads of state implemented a series of privatizations and subsidy curtailments that provoked a resurgence of class-motivated political aspirations among broad layers of society (Roberts 2003, 58). Hugo Chávez filled this vacuum with his ascent to the presidency in 1999.

Though Chávez advocated a pro-poor political agenda - many of whose aspects were incorporated into the new constitution - he initially pursued a 'social democratic' economic policy, neither nationalizing the commanding heights of the economy nor further privatizing it (Buxton 2003, 124). Yet the regime radicalized its policies as el proceso progressed. In 2001, the government decreed a set of 49 laws that provided the juridical framework for numerous transformation-oriented initiatives. According to Ellner (2008, 113), the two most important of these laws were: (i) the Hydrocarbons Law, allowing the state to harness a greater part of the national oil wealth; and (ii) the Land Law, allowing for the expropriation of underutilized lands, which was framed as a 'war against latifundismo'. ${ }^{21}$ These legal inroads into the extant property structure precipitated a formidable reaction: following opposition mobilization, media fabrication and disloyalty at the heights of the military, Chávez was ousted from office for 48 hours in April 2002 (Coronil 2011; see also Ellner 2008). Then, in December 2002, state oil company executives led a lockout, paralysing the oil industry for 8 weeks. Meanwhile, violence directed at peasant radicals, believed to be the work of latifundistas and other agrarian elites, escalated in the countryside (Enríquez 2013; interviews, 31 July 2012 and 12 August 2012).

Despite resistance, the state's partial reinsertion into the oil economy has provided it with the resources to initiate myriad pro-poor projects. The most exemplary of these are the government's misiones, social-welfare initiatives in health, education, job training and subsidized food, as well as one of the most recent, the Gran Misión AgroVenezuela (see below). Internecine conflict has often punctuated relations between these new initiatives and state structures inherited from the past (Ellner 2008, 168-9). Nonetheless, the ways and extent to which such conflict impacts the state's capacity to pursue its goals have escaped systematic attention.

Scholars have generally approached the politics of el proceso in one of three ways. One group of researchers focuses on the political heights of the regime, arguing that the qualities of Chávez (Roberts 2003; Cannon 2009) or the state's popularly-oriented juridical structure (Ciccariello-Maher 2007) explain the political agenda and the nature of social change in contemporary Venezuela. Unfortunately, such research has generally failed to examine how top-down initiatives have translated into on-the-ground state practices. A second group of researchers argues that the popular classes are the motor force of el proceso as they engage with popularly-oriented state initiatives (Fernandes 2010). That is, the popular sectors spearhead 'everyday state making' (Schiller 2011, 119; the term is from Joseph and Nugent 1994). Yet, because these popularly-oriented initiatives were set up alongside the old state apparatus -

21 Latifundios are very large, private farms, typically with substantial areas of unused land. They are also commonly characterized by low yields, limited investments made in them and modest levels of technology employed on them. They also do not usually employ full time wage-labourers but, rather, more provisional labour arrangements prevail on them, which may entail non-monetary transactions. 
effectively prolonging a configuration of 'dual power' - it is important to understand the relationship between the new and old structures, and relations within the new one(s), in order to assess the impact of popular politics on the state's agenda. A third perspective sheds light on the divergent political interests and conflicts among fractions of el proceso's political elite (Ellner 2008, ch. 6). Research on the contingent nature of decision-making provides valuable insights into policy-making in Venezuela, but does not contribute to our comprehension of the way in which these policies play out. Thus, neither the top-down, the bottom-up, nor the elite-agonistic perspective is sufficient for understanding the capacity of the country's dualinstitutional state to pursue its goals. In the analysis that follows, we focus on one aspect of the augmentation and partial transformation of state structures and state-society relations during el proceso: the politics of agrarian transformation in the State of Portuguesa.

\section{Three Pillars of Agrarian Policy}

The Chávez administration launched a number of national-level initiatives with the objective of promoting agrarian transformation. ${ }^{22}$ All of these have sought to increase food production. In addition, the Venezuelan state sought to achieve what agrarian studies scholars have typically referred to as food sovereignty, which is ensuring local and ecologically-sustainable production of culturally-relevant food products in sufficient quantity to feed the population. ${ }^{23}$ Even though the constitution of 1999 articulated the objective as attaining 'food security' - which it defined as guaranteeing sufficient and stable access to food for the population within the national context (República Bolivariana de Venezuela 1999, Article 305), it also called for that production to be ecologically sustainable and based on a more equitable agrarian property structure. These latter elements bring the state's initial objective into the fold of most scholars' idea of the former concept. In 2008, the government stated that its goal was to achieve food sovereignty (República Bolivariana de Venezuela 2008, 2). However, despite the fact that the state said that it was seeking food security at first and food sovereignty later on, in actual practice, the state has shifted from pursuing a food sovereignty agenda to a food security one. Before we explain what led to this shift, we outline three pillars of the Chávez government's agrarian policy.

The first, and perhaps most fundamental, of these transformation-oriented initiatives has been the ratification of the Land Law and its subsequent implementation. The Land Law applies when an 'owner' is unable to document that s/he has title to some portion of the land $\mathrm{s} /$ he claims to own or when s/he fails to utilize it. It allows the state to identify and redistribute such land in order to: (i) reform the property structure and reduce landholding inequality; (ii) provide economic livelihoods to under- and unemployed Venezuelans; and (iii) increase food production. By late 2012, approximately 6.33 million hectares had been 'rescatado', or 'recovered', nationwide through the application of the Land Law (MPPAT, cited in PROVEA 2013, 273). Although some of this land was redistributed to individuals, the state preferred to support cooperatives and civil associations in order to promote a more

22 In describing these initiatives, it is important to note that our objective is to provide the backdrop for an analysis of the nature of the contemporary Venezuelan state and the ways in which it supports, or fails to do so, novel forms of productive activity. It is not our intention to assess the productivity of the agrarian economy of the nation as a whole, nor that of Portuguesa. While this latter project would certainly be worthwhile, it is a separate endeavour from that which we have set out for ourselves.

23 See further Wittman (2011); and for an insightful comparison of food security and food sovereignty, see Patel (2009). As will be discussed below, this conception of food sovereignty has begun to be challenged (see especially Kappeler 2013). 
collectively-oriented approach to production. What this has meant is that the medium-sized farm sector - which includes cooperatives - has grown in acreage as land has been redistributed from the 'recovered' estates, while the small-sized farm sector has not. ${ }^{24}$ Those who receive the land have usufruct rights to it, as well as to the productive investments made on it. They are able to pass on these rights to their offspring, but not to sell them.

Consisting of one or more cooperative or civil association unit(s) of production, Fundos Zamoranos were initially a crucial player in the government's efforts to attain food sovereignty (see below). However, by 2009, the Venezuelan government had retreated from promoting cooperatives in most parts of the economy. The general consensus was that the number of such enterprises had grown too rapidly, that they had failed to solidify into viable economic actors and that a different form of organizing production was in order. ${ }^{25}$

Second, another important component of agrarian policy has been the pursuit of ecologically sustainable agricultural production. ${ }^{26}$ This goal was enshrined in the constitution of 1999, the Land Law of 2001 and the revised Land Law of 2005, and has translated into the promotion of an agro-ecological approach to farming. Agro-ecology entails utilizing nonchemical means of controlling pests and sustaining soil fertility, and fostering biodiversity (Altieri 1995). Politically and socially, agro-ecology revalidates traditional and small-scale production practices and those who engage in them (Altieri and Toledo 2011). ${ }^{27}$

Drawing an interim balance sheet - despite some land redistribution, establishing new productive relations and promotion of sustainable agriculture - by 2009-10 it was clear that food production was not increasing at a rate that would satisfy domestic consumption needs. In addition to population growth, which resulted in the need for increased food production, the government's other policies had succeeded in substantially reducing poverty in Venezuela (Weisbrot and Johnston 2012). This has further increased demand for foodstuffs. However, domestic food production has not kept pace with growing demand (for further information about patterns in food-crop production, see Appendix A; Gutiérrez Socorro 2013), let alone with the ongoing problem of smuggling subsidized and price-controlled foodstuffs out of the country (see e.g. Arráiz 2014). In order to satisfy increased domestic consumption, the government has reoriented itself from a radical agrarian-transformation agenda to spending an increasingly greater amount of its resources on importing food (Hernández 2010, 183-4). According to Purcell (2013), state-supported, reformed-sector farms have failed to produce sufficient quantities of food due to lack of exposure to the discipline of the international market. While the international dimension is quite important, below we offer a different

24 To be more specific, while farms larger than 1,000 hectares in size have diminished from controlling 46 per cent of farm acreage in 1997/98 to 40 per cent in 2008, farms between 20 and 1,000 hectares in size have grown from controlling 48 per cent of farm acreage in $1997 / 98$ to 54 per cent in 2008 (CIAAL 2011). In this sense, Delahaye (2008) argues that the present period of agrarian change (which the Land Law of 2001 set in motion) has represented a continuity with the previous agrarian reform (which was initiated in 1960), rather than a significant break from it, despite the rhetoric of the Chavista leadership and movement. See also Delahaye (2001).

25 Delahaye (2008) would not have been surprised at this shift in course and consensus about them. He argues that Venezuela has a long history of promoting cooperatives, especially during agrarian reform processes. When they have failed to produce the economic and productive outcomes hoped for, the government has repeatedly retreated from its endorsement of them.

${ }_{26}$ Here, as will become clear, we are focusing on practices employed on the farm. The larger question of whether small-scale farming, in a collective fashion or otherwise, is sustainable in political-economic terms, given the rentier nature of Venezuela's economy, is a separate issue (cf. Purcell 2013).

27 Proponents of agro-ecology argue that these practices can also be used on medium-sized farms, and that the combined agro-ecological production of small- and medium-sized farms is capable of feeding the population (see Altieri and Nicholls 2002; Badgley et al. 2007). 
Table 2. The shifting emphasis in the state's agrarian political-economic agenda

Period

Property structure prioritized

Small farms, coops State farms Large farms

$\mathrm{T}_{0}$ : punto fijo period (decades prior to ca 2001)

$\mathrm{T}_{1}$ : food sovereignty agenda (ca 2001-10)

$\mathrm{T}_{2}$ : food security agenda (ca 2010-present)

$\begin{array}{lll}\text { No } & \text { No } & \text { Yes } \\ \text { Yes } & \text { No } & \text { Mixed } \\ \text { No } & \text { Yes } & \text { Yes }\end{array}$

explanation for why some of these farms have encountered considerable difficulties in meeting the government's initial expectations for them.

In the context of domestic production shortfalls and continued reliance on imports, the Chávez government unveiled its third major agrarian transformation initiative, the Gran Misión AgroVenezuela (GMAV), in January 2011. The Misión has had three principal objectives: to expand the area under production, to increase staple crop production and to promote urban agriculture. The GMAV was intended to support increased production in the reformed sector, as well as among small- and medium-sized producers more generally. But large growers have also benefited from the Misión. ${ }^{28}$ In working towards its objectives, significant amounts of agricultural credit and machinery/implements have been distributed to farmers under the GMAV's auspices. In just the first 8 months after the initiation of the Mision, more than 170,000 farmers received credit from public banks - the Development Fund for Socialist Agriculture (FONDAS) and the Agricultural Bank of Venezuela (BAV). ${ }^{29}$ During that same period, 14,000 farmers received machinery and other agricultural equipment, and the Misión assisted an even greater number with developing irrigation systems. In addition, GMAV has facilitated road construction in rural areas. Thus, massive quantities of funding have gone into GMAV's efforts to stimulate agricultural production, constituting a contemporary 'sowing of the oil'. In conjunction with GMAV's inauguration, the nationalization (in October 2010) of the country's largest agricultural inputs supplier - AgroIsleña, now AgroPatria - was intended to ensure the availability of inputs in order to augment and transform production. ${ }^{30}$

Nevertheless, a general reorientation away from pursuit of food sovereignty has been observable in recent years (cf. Hernández 2010). We focus on the reasons for the transition from the dual-institutional state's initial prioritization of food sovereignty to its later food security agenda (Table 2). This shift has entailed a change in the state's emphasis, from promoting small farms and cooperative agricultural initiatives through land redistribution - in part to contribute to the food sovereignty agenda $\left(\mathrm{T}_{1}\right)$ - to consolidating state farms and a rapprochement with large farmers (with increased food imports to supplement domestic production) - the food security agenda $\left(\mathrm{T}_{2}\right)$.

\footnotetext{
28 The requirements for receipt of credit through GMAV are as follows: to be registered as an agricultural producer with the Misión; to have a land title (even if only a provisional one); and to have a letter attesting to one's status as an agricultural producer from one's local Communal Council (interview, 10 July 2012). Hence, there is no clear delimitation above which a producer is too large to receive benefits from GMAV.

${ }_{29}$ See http://www.gobiernoenlinea.gob.ve/home/noticia_detalle.dot (accessed 11 November 2012).

30 AgroPatria's objective was to sell subsidized agro-inputs to all kinds of producers, including small- and medium-sized farmers. However, large private growers also purchase inputs from AgroPatria (and they are at an advantage because they purchase inputs en masse, through their peak sector organizations, and stockpile them to circumvent scarcity).
} 
Table 3. INTI-recovered land in Portuguesa, 2008-11

\begin{tabular}{lcrrr}
\hline & 2008 & 2009 & 2010 & 2011 \\
\hline Area recovered (hectares) & 10,560 & 6,464 & 16,254 & 13,004 \\
Percentage of land in state & 0.69 & 0.43 & 1.07 & 0.86 \\
\hline Total area in state (hectares) & $1,520,000$ & & & \\
\hline
\end{tabular}

Source: Unpublished INTI data.

\section{Portuguesa, Venezuela's Arepa Basket ${ }^{31}$}

In the interest of examining the impact of these national-level initiatives, we chose to look closely at their application, and agrarian policy in general, in a key food producing state: Portuguesa. In recent years, Portuguesa has contributed the majority of domestic rice production, a significant part of corn production and a considerable part of domestically-produced sorghum (see Appendix B). Because these crops are essential for the Venezuelan diet (both for direct consumption and for livestock feed), and due to the importance - derived from the 'Iron Law' - of maintaining continuity in this state's contribution to domestic food production, Portuguesa is an ideal site to study the dynamics of agrarian political-economic transformation under a dual-institutional state.

Much of Portuguesa's production is attributable to larger-scale, highly mechanized and irrigated farms. In fact, farms larger than 200 hectares in size control more than half of Portuguesa's agricultural land. ${ }^{32}$ Furthermore, by 2008, approximately 30 per cent of this state's farms relied upon tractors for their production, compared to the national average of 15.6 per cent (ibid.). Although the state played a key role in the development of Portuguesa's agricultural modernization, at this point in history the better part of these grain-producing farms are privately owned by individuals/families or corporations. ${ }^{33}$ Alongside such farms, a substantial agricultural goods-processing industry emerged during the mid-twentieth century (Figueroa 1990). Most of this private economy persists, suggesting the limited nature of the transformation of the agrarian property structure in Portuguesa to date. As Table 3 shows, the National Land Institute (INTI) - which is responsible for applying the Land Law - has appropriated only a miniscule amount of land there in recent years. That might, at first glance, appear to contradict the logic of the Law. However, its principal intent was to identify and redistribute unused land. Portuguesa's highly-productive farmers who have continued to cultivate the better part of their land have, by and large, not been affected.

During the first decade of the twenty-first century, the unused land affected by the Land Law was often redistributed to cooperatives, civil associations, Fundos Zamoranos and

\footnotetext{
31 Arepas, which are central to the diet of Venezuelans, are a tortilla-like food made from corn that forms a pouch for filling with a variety of edible items.

See MPPAT (2008). It should be noted that there is little agreement worldwide about how different farm size categories should be delineated at this point in time, given a general consensus that more than just acreage should be taken into account. Even within Venezuela there are discrepancies in this regard. For example, CIAAL (2011) divides farms into three size categories: less than 20 hectares in size, 20 to 1,000 hectares in size, and more than 1,000 hectares in size. Yet, for AgroPatria, small farmers are defined as having between 0 and 90 hectares (interview, 10 July 2012); and for FONDAS, small farmers have less than 20 hectares, and mediumsized producers have between 20 and 100 hectares (interview, 16 July 2012).

33 Ríos and Carvallo (1990) describe this process, as part of their larger discussion of the changes that occurred in Venezuelan agriculture following the adoption of oil production for export.
} 
individual peasants. Fundos Zamoranos - six of which were formed in the State of Portuguesa between 2004 and 2008 (interview, 12 July 2012; pers. comm., 28 March 2015) were established on several of the largest expropriated farms. Their members were recruited from both urban areas - through the Return to the Countryside (Vuelta al Campo) programme, which trained unemployed urban dwellers in farming techniques and cooperative production - and from the surrounding countryside (interviews, 26 July 2012 and 7 August 2012). ${ }^{34}$ The state also recently nationalized several farms and converted them into state enterprises, or UPSs.

At the same time, small- and medium-sized producers continue to have a notable presence in the State of Portuguesa. Farms smaller than 20 hectares in size control approximately 11 per cent of the agricultural land in Portuguesa, while those between 20 and 200 hectares in size control approximately 35 per cent (MPPAT 2008). They are especially important in the production of coffee, while also producing a variety of other food products. Given its objective of attaining food sovereignty, the state provides these independent producers with loans and subsidized inputs.

Finally, Portuguesa's rural social structure includes a population that participates in agriculture through the sale of its wage labour. A rough estimate of those who constituted the rural wage-labour force in this state at the end of the first decade of the twenty-first century is $35,000 .^{35}$ Some part of this population, along with some of the land-poor, make up those who are still seeking land to farm through the application of the Land Law at the current time. $^{36}$

In the analysis of agrarian change in the State of Portuguesa that follows, we focus primarily on interactions between the state and cooperative forms of production, most especially the Fundos Zamoranos. We have chosen to direct our attention especially towards these forms of production, as they were key actors in the state's efforts to transform agriculture for most of the past decade.

\section{THE STATE, FUNDOS ZAMORANOS AND THE PROPERTY STRUCTURE}

INTI began establishing Fundos Zamoranos in 2001 as a central component of the state's initial food-sovereignty initiative (interview, 8 August 2012). The agency oversaw all aspects of these farms, coordinating infrastructural development executed by the Rural Development Institute (INDER) and providing Fundos Zamoranos with the direct assistance and support necessary to produce on the land. However, as the state both established relevant new agencies and refashioned old ones, INTI progressively relinquished its various responsibilities to specialized bureaus. Initially, INTI promoted sustainable farming on the Fundos Zamoranos; now the Foundation for Training and Innovation for Rural Development (CIARA) and the National Institute of Integral Agricultural Health (INSAI) are the primary agencies responsible for promoting sustainable agricultural practices. Initially, INTI extension technicians worked directly with the Fundos Zamoranos; now CIARA is responsible for this. Initially,

\footnotetext{
34 However, those who came from rural backgrounds seemed to have had greater staying power.

35 This calculation is based upon the Economically Active Population occupied in Agriculture and Hunting in Portuguesa in 2011 (73,107 persons), minus the number of those who owned land in 2008 (35,889). The first figure comes from the Instituto Nacional de Estadística (INE 2014, Cuadro 01. Portugesa) and the second comes from MPPAT (2008).

36 We were told that there is still demand for land to be turned over to land-poor and landless agriculturalists (interviews, 12 July 2012 and 13 August 2012).
} 
INTI provided credit to the Fundos Zamoranos (and oversaw credit dispersion from the Development Fund for Agriculture, Fishing, Forestry and Related Activities, or FONDAFA); now FONDAFA's successor, ${ }^{37}$ the Development Fund for Socialist Agriculture (FONDAS) and the Agricultural Bank of Venezuela (BAV) service the Fundos Zamoranos directly. The reallocation of INTI's original responsibilities has put distinct agencies in charge of articulating with the Fundos Zamoranos for their specific purposes.

Given the kind of lands upon which the Fundos Zamoranos were established - lands that had previously been abandoned or left fallow - state support has been very important. The fact that the land was not put to productive use constituted the initial justification to apply the Land Law and (re)distribute the plots to those who promised to produce on them. Moreover, because the land had, heretofore, been un(der)used, redistribution could only augment agricultural goods production - that is, it would not directly impact the agrarian elite's productive activities. Yet, by the same token, this has left such beneficiaries with a distinct economic handicap - a disproportionate share of undeveloped, and at times poorquality, land. The following description of one of Portuguesa's Fundos Zamoranos will give the reader a sense of the lands that the Fundos have received from INTI.

The Fundo Zamorano Batalla de Araure, located in the municipality of Guanarito, is 10,100 hectares in area (interview, 27 July 2012). It represents only part of the former latifundio it was taken from, the remaining 18,000 hectares of which were not incorporated into the Fundo. The Fundo is comprised of 19 separate economic entities - including cooperatives, civil associations and incipient organizations ${ }^{38}-$ spread throughout its area. It is partially plains land and partially jungle, and had been abandoned for about 15 years before conversion into a Fundo Zamorano (interview, 26 July 2012). Most of its residents live in rustic accommodations. Overland travel within the Fundo is extremely difficult; in fact, its former latifundista owner used to arrive via airplane. Once INTI turned the land over to the Fundo, INDER laid about 17 kilometres of dirt road and installed two bridges to access Batalla de Araure. But the interior of the Fundo Zamorano remains difficult to pass through during the 6-7 months of the rainy season each year. ${ }^{39}$ It is important to note that the two other Fundos that we visited in Portuguesa were established on farms that were considerably smaller and less remote than Batalla de Araure. Although the conditions on them were somewhat less problematic, they were still far from ideal.

Despite the remote locations and underdeveloped lands dedicated to Fundos Zamoranos, initial expectations about what they might achieve - in terms of contributing to the effort to attain food sovereignty - were great. However, after about a decade, the prevailing sentiment among state officials was that the Fundos Zamoranos had not been successful in increasing output or in affecting a transition to sustainable production. In our attempts to find

37 FONDAFA had its roots in the Agricultural Credit Fund, which was established in the 1970s under President Carlos Andrés Pérez. In late 1999, the Fund was re-inaugurated by the Chávez government as FONDAFA. Yet, given the early date of its renaming and the fact that the depth of the changes embodied in the Land Law of 2001 had yet to be articulated, one could legitimately consider this institution a holdover from the past. FONDAFA was eventually replaced with FONDAS in 2008, because the former was no longer solvent. However, FONDAFA was also highly discredited as an institution due to a corruption scandal involving it (cf. Gunson 2006; de Cordoba 2007).

38 Cooperatives and civil associations are sociologically comparable in that they are both economic units that require more than one person to receive official recognition and preferential assistance; they are merely two different forms of 'juridical persons'. But because establishing a civil association requires three members, as opposed to five for a cooperative, the former are considered easier to establish (interview with civil association member, 27 July 2012).

39 It took one of the co-authors nearly 2 hours to travel by tractor between the cooperatives and civil associations near the access road to those in the middle of the Fundo. 
Figure 1 FONDAS-Portuguesa loans, 2008-11

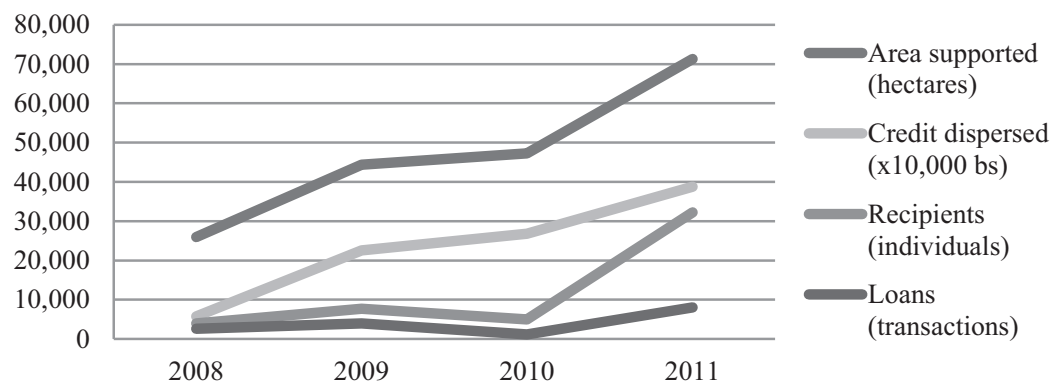

Source: Gran Misión AgroVenezuela, 2011: 'Logros FONDAS años 2008-2011, Estado Portuguesa' (see FONDAS 2011, 3).

Note: The number of recipients exceeds the number of loans because FONDAS extends loans to many juridical persons consisting of more than one individual, thus issuing fewer loans that reach more recipients. We attained several different discrepant sources reporting area, credit, recipients and loans. The trends, however, are consistent across our sources.

the reasons for this lack of success, we often heard accounts of the absence of collective consciousness among Fundo Zamorano members. We were also told that farmers did not believe that sustainable farming techniques would guarantee their production and that consumers did not value sustainably-produced goods, a combination that inhibited significant advances in this direction. Although we consider lack of consciousness and cultural schemes to be consequential, by focusing instead on the question of agency capacity and inter-agency coordination, we aim to identify factors that have contributed to making such practices seem unreasonable to farmers.

\section{Agency Capacity and Agency Incapacity}

In addition to providing the land, the state has made considerable efforts to facilitate production on reformed-sector farms in general and on Fundos Zamoranos in particular. For example, it set up the Pedro Camejo Socialist Enterprise ${ }^{40}$ in 2007 to provide essential machinery services to farmers. These services include pesticide application, mechanical rice harvesting, tilling the soil in preparation for planting and similar activities. The enterprise pays special attention to small farmers - generally defined as those with less than 20 hectares of land - by providing them with its services at heavily subsidized prices. ${ }^{41}$ This initiative constitutes a crucial form of support for many farmers, particularly the land-poor and recent land-redistribution beneficiaries.

The state has also provided vast amounts of credit to agrarian producers. Between 2003 and 2008 alone, the amount of public agricultural credit extended at the national level increased by 791.5 per cent, growing from approximately 1.8 million to 16 million Bolívares (Hernández 2010, 171, cuadro IX.1). Credit provided by just BAV grew from 6.4 million Bolívares in 2008 - the year in which this institution was founded - to 55.7 million Bolívares in 2012 (PROVEA 2013). Farmers in Portuguesa have been among the recipients

40 Pedro Camejo pertains to the Ministry of Agriculture, or MPPAT.

41 For example, their charges for ploughing were roughly a fifth of what private machine operators would charge (interview, 26 July 2012). 
of this largesse. As Figure 1 shows, the state has directed a growing amount of credit to land-redistribution beneficiaries and their non-beneficiary small- and medium-sized producer counterparts in Portuguesa, particularly since the advent of the Gran Misión AgroVenezuela in 2011.

Because Fundo Zamorano inhabitants do not come to farming with significant resources or savings, they rely heavily on this credit to allow them to plant, cultivate and harvest many of their crops, as well as to purchase livestock. Yet the Fundos Zamoranos that we visited had experienced considerable problems associated with credit. ${ }^{42}$ Unavailability or tardiness in the delivery of credit can greatly influence whether they have a successful crop cycle or not, and can prevent small farmers and land-distribution beneficiaries from efficiently cultivating all of their land. One of the Fundos where we conducted interviews, in the municipality of Turén, had received its credit too late in the season for use in financing its crops. Hence, residents had not been able to dedicate as much acreage to corn cultivation as they had planned. Moreover, lack of credit for larger, multi-year projects has the potential to be extremely detrimental to farm development efforts. One of Turén's Fundos Zamoranos had experienced a delay of 8 years in receiving the disbursement of a long-term loan for livestock that FONDAS had promised. In May 2012, the lender finally granted an initial part of the credit for the construction of a milking shed. But the second part, which the Fundo members needed in order to purchase the first ten cows, had yet to arrive at the time of our visit that August, due to FONDAS's failure to complete an inspection of the facilities (interview, 8 August 2012). Such bureaucratic delays stymie production and farm development.

Credit agencies have also failed to uphold their end of purchasing agreements they struck with Fundo producers. Members of another Fundo we became acquainted with received a loan from FONDAS to produce green peppers and other vegetables, with the promise that their creditor would market the produce. But upon harvesting their crop, FONDAS simply failed to pick it up (interview, 27 July 2012).$^{43}$ Fundo inhabitants watched their goods rot and found themselves indebted to FONDAS for the amount of the loan (for which they were in debt forgiveness negotiations at the time of fieldwork).

We heard from numerous interviewees on and off the Fundos Zamoranos about the incapacity of the state to ensure a fluid process of commercializing the produce that results from state investments in agricultural production. This can take several forms, including failing to open purchasing centres to coincide with harvests and not paying for produce in a timely fashion. At a town hall meeting that we attended, farmers from the surrounding farming communities complained about the state's limited marketing capacity (field notes, 12 July 2012). As one state official lamented: 'These [smaller] producers don't have vehicles, so when they arrive in town, if the purchasing centre isn't open, they have to sell their produce to whomever. Moreover, the intermediaries have cash' (interview, 12 July 2012).

Interestingly enough, FONDAS has plans to assume a much more central role in the commercialization of the Fundos' produce. There are multiple motivations for this. They include the fact that, by purchasing the produce, FONDAS gains more control over repayment of its loans (interview with FONDAS official, 1 August 2012). In addition, there is concern within the agency about how much private intermediaries make from the sale of farmers' produce, putting farmers at a great financial disadvantage. State officials are also of

\footnotetext{
42 Problematic access to credit appeared to exceed the bounds of the Fundos Zamoranos and presents problems for small farmers in general (field notes, 12 July 2012).

43 Page (2011) describes another instance in which a state agency promised to market vegetables its representatives had convinced the cooperative to produce, and then failed to come through on marketing them.
} 
the opinion that, because state agencies provide producers with credit, subsidized inputs and technical assistance, the latter have at least an implicit obligation sell their produce to the state (interview with MPPAT officials, 11 July 2012). In order to increase its commercialization capacity, FONDAS was bolstering its new marketing division at the time of fieldwork, and had facilitated up to 24 Mercados Zamoranos, or farmers' markets, during each of the previous 3 years (interviews with FONDAS officials, 16 July 2012 and 1 August 2012). Yet, all of these rationales and efforts do not mean that the state actually has the capacity to market such produce.

Peasant organizations have responded to the state's commercialization shortcomings in various ways. One incipient organization, the Consejos Campesinos Socialistas, initiated a project intended to allow farmers to engage in barter with their produce (interview with Consejos Campesinos Socialistas organizer, 31 July 2013). The Frente Nacional Campesino Ezequiel Zamora (FNCEZ) - the principal peasant organization in Venezuela - maintains that improving commercialization is even more urgent for farmers than access to land. They complain that 'FONDAS only engages in marketing on a very small scale' and '[only] receives "flagship products" like corn' from the producers it lends to (interview with FNCEZ leader, 12 August 2012). Although FONDAS finances other crops, it does not assist those who grow them with marketing. 'The papaya producer is left on his/her own to sell his/her crop. And, who receives the crops of those who finance their own production?' they ask. Middlemen intervene, buy cheaply from vulnerable small farmers and turn a profit. In order to compensate for the state's limitations vis-à-vis commercialization, the FNCEZ threw its support behind construction of a food-processing plant that would purchase produce from farmers. Funding for the plant was to come from the state, and FNCEZ intended to take charge of its operation. Yet the state only provided funds to begin the project (interview with FNCEZ leader, 25 July 2014). Its completion and operability has, therefore, been indefinitely postponed.

Another area in which agency-level capacity has been limited is with respect to the provision of the inputs needed to engage in sustainable agricultural production. Despite the state's expressed commitment to a transition to sustainable agriculture, the relevant agencies have not been able to produce sufficient supplies of the various inputs required for such practices. There are several distinct state agencies that are supposed to play a role in facilitating adoption of sustainable farming practices, including providing inputs to farmers. INSAI is one of the principal state agencies involved in promoting agro-ecology, but it produces very few inputs (interview, 9 July 2012). INSAI supplies free bio-inputs on a very small scale, and its officials assume that farmers will be able to purchase additional bio-inputs from the stateowned agro-input vender, AgroPatria. ${ }^{44}$ However, at the time of our fieldwork, AgroPatria still had far fewer bio-inputs to sell than existing demand called for (interview with AgroPatria representatives, 10 July 2012).

As is true of other states in Venezuela, the main body in charge of producing agro-inputs in Portuguesa is another state agency, the National Institute of Agricultural Research (INIA). Having been in existence since the 1960s, INIA - the state's premier agricultural research agency - has abundant experience innovating new methods of production. INIA also has had plentiful resources when compared to all other agencies within the Ministry of Agriculture

44 INSAI's Portuguesa office is responsible for various other tasks besides promoting sustainable agriculture. It oversees the health of livestock throughout the state, inspects agricultural produce for pests and diseases en route to market or storage facilities and extends the guías de movilización (permits) required to transport agricultural goods (interview with INSAI representatives, 2 July 2012). Consequently, its capacity to support agro-ecology has been restricted. 
(MPPAT) (interview with former INIA representative, 30 June 2012). Thus, in theory, INIA should be well poised to contribute to the effort to promote agro-ecology in the State of Portuguesa by means of research pertaining to, and production of, bio-inputs. However, its objectives have been focused instead on increasing production in general (interview with INIA researcher, 11 August 2012). Hence, these three distinct state entities, which together have the responsibility to support agro-ecological production, have not been able to provide the inputs that are essential for a transition to more sustainable production practices. ${ }^{45}$

In sum, we have discussed several instances in which state agencies have been unable to fulfil their promise, in terms of promoting transformation-oriented initiatives geared towards achieving food sovereignty, thereby undermining these initiatives. Whether it was the effort to facilitate development on the Fundos, through timely credit provision or assistance with marketing, or the adoption of agro-ecological practices, the capacity necessary to support it was clearly lacking. A few of the agencies that evidenced this weakness - most especially FONDAS and INIA - have their origins in previously existing agencies, suggesting that they have yet to fully identify with the state's new agenda.

\section{Inter-Agency Coordination, Lack of Coordination and Conflict}

Lack of inter-bureau coordination and conflict has further hindered agrarian transformation. While agencies often meshed smoothly with one another, we observed two problematic varieties of inter-agency division of labour, the first when one or more agency worked to influence the practices of another, and the second when the goals and practices of two agencies directly opposed one another. We discuss both varieties of lack of inter-agency coordination in turn.

To be eligible for credit from either of the state's two main creditors - BAV and FONDAS - all farmers in Venezuela are required to provide copies of several documents, including a land title (even if only a provisional one, a carta agraria). Obtaining land documents from INTI is often a long and arduous process. Not surprisingly, many land-reform beneficiaries have yet to obtain documents for the farms they work. Nonetheless, since they need such documents to process their loans, the BAV actually works to coalesce groups of farmers with similar land titling deficiencies, after which it calls a meeting with INTI in order to apply pressure to expedite the titling process (interview, 23 July 2012). Responding to the needs of farmers, and being cognizant that it will have more leverage than individuals or even a group of farmers, the BAV employs an ad hoc strategy to influence INTI to expedite normalization of land holdings. ${ }^{46}$

Interestingly and perhaps ironically, such cross-agency influence runs in the opposite direction as well: INTI has also insisted that FONDAS grant loans without the proper land documents. For instance, during a town hall meeting that we observed, an INTI representative demanded that credit be made available for a producer - who had been on his land for 6 years - lacking proper documentation (field notes, 12 July 2012). We were able to confirm

\footnotetext{
45 For the number of employees in select state agencies, see Appendix C.

46 It is essential to note, however, that there have also been occasions on which the peasants have organized themselves to force the state's hand. In Portuguesa, probably the highest-profile instance was when a group of peasants pressured the state to expropriate lands owned by the Smurfit cardboard company. After camping on the side of the highway adjacent to the estate for about 4 months - and possibly (though reports are contradictory) invading and planting on the land - the state expropriated some 3,800 hectares from Smurfit and divided about 500 hectares of that into 2 hectare plots for about 60 families, most of whom received land titles in March 2012 (interview, 28 July 2014).
} 
that there have been instances in which FONDAS has extended credit without proper documentation (interview, 1 August 2012; field notes, 12 July 2012). Though this practice is illegal, it may have been necessary to reach some small producers, FONDAS officials reasoned. As one FONDAS functionary put it, 'not everything that is just is legal' (interview, 1 August 2012). However, FONDAS has been eliminating the 'just' (though illegal) practice of lending without all the required documents. Thus, although state agencies have attempted to influence one another in pursuit of the things that they consider to be right, it is unclear how long such propitious conjunctures will endure.

Moreover, instances in which agencies fail to cooperate with one another are also abundant, preventing the sum of their activities from forming a cohesive, transformation-oriented institutional structure. The provisioning of credit is one such area in which lack of interagency coordination has resulted in less than ideal support for agrarian transformation. There are multiple agencies that offer agricultural credit to producers. This has been an issue since the Chávez government adopted its policy of promoting agricultural expansion and also characterizes other states in Venezuela (see e.g. Enríquez 2013). In Portuguesa, the agencies that provide credit to small- and medium-sized individual farmers and cooperatives include FONDAS, the BAV, the Institute for Promoting and Strengthening the Communal Economy (INPROFEC), PDVSA Agrícola, Banco Bicentenario and BAndes. Key among these are the first two (both of which form part of the MAT). ${ }^{47}$

As is true throughout Venezuela, the plethora of lending agencies reflects the Chavista leadership's commitment to expand access to this important resource. However, it also suggests a level of redundancy that may contribute to a lack of efficiency in the use of agricultural capital. And it increases the possibility that clients who have failed to repay a loan from one agency might simply call upon another for additional credit, or might take out multiple loans from different credit agencies for a single purpose. Ostensibly, a system of controls has been established to ensure that such eventualities do not occur. However, several state functionaries acknowledged that there are still instances when clients outmanoeuvre the system and obtain credit from more than one agency (interview with FONDAS officials, 1 August 2012; interview with BAV officials, 23 July 2012). While abundant lending has made credit available to many who never had access to it before, this kind of redundancy and the possibilities for abuse that it facilitates undermine the viability of that same credit system as a means of agrarian transformation.

Further precluding the government's aims, at the level of the Fundos Zamoranos, state agencies directly contradict one another with respect to promoting sustainable production. In allocating credit to Fundo Zamorano cooperatives and civil associations (as with all other entities to which they lend), FONDAS, their main creditor, uses a 'technological package' to calculate how much financing is needed and to determine the manner in which the credit it provides is to be spent. Both the contents of the technological package and FONDAS extension technicians' advice to farmers are entirely consistent with the conventional, petrochemical-based agriculture paradigm (interviews, 27 July 2012 and 7 August 2012). Meanwhile, CIARA is responsible for overseeing the general development of the Fundos, and

47 To give some sense of the size of the BAV's and FONDAS's operations in Portuguesa, the acreage the first of these institutions financed there (33,307 hectares) during the first 11 months of 2012 represented approximately 19 per cent of the acreage it financed in the entire country; and that of FONDAS (45,999 hectares) in the first 10 months of 2012 represented approximately 18 per cent of the acreage it financed in the whole country (PROVEA 2013, 277-8).

INPROFEC is a Portuguesa State Government agency. It provides small loans to agricultural producers and small- and medium-sized industry (interview, 18 July 2012). 
for providing them with ongoing technical assistance. CIARA's entire raison d'être is bound up with the promotion of sustainable agriculture, and its extension workers provide only agroecological advice. Thus, although both FONDAS and CIARA are integral to the functioning of Fundos Zamoranos, they have contradictory policies with respect to the practices that Fundo farmers should employ. CIARA is particularly disadvantaged, though, because it does not offer credit; CIARA officials reckon that they have far less leverage than a credit-granting organization in influencing agricultural practices (interview, 12 July 2012), despite being the key state agency for fostering agro-ecological practices on the Fundos Zamoranos (and elsewhere). As a result, instead of ensuring that the Fundos Zamoranos reach their full agro-ecological potential, CIARA is forced to oscillate between giving their residents technical assistance that contradicts that of FONDAS, and not assisting them at all.

This kind of inter-agency conflict - and unevenness in resource availability - has weakened the agencies dedicated to promoting the conversion from conventional to sustainable agricultural production. FONDAS's approach to lending has not embraced the state's food sovereignty agenda. In this sense, it has continued to adhere to the 'old ways' characteristic of the agency it replaced. This, combined with the agency's relative power and its disagreements with CIARA, has given rise to a contradictory division of labour that has undermined the capacity of the state's change-oriented institutional structure to affect the transition to food sovereignty.

\section{Small and Reformed-Sector Farmers, Extant Property and Sustainable Agriculture}

Small and reformed-sector farmers are forced to work with the incapacities of the transformation-oriented state institutional structure in the context of the limited modification of the property structure. This has, ultimately, sabotaged their sustainable productive initiatives. As a leader of one of the Fundos Zamoranos in Turén lamented, the entrenched patterns of conventional production practices on adjacent, private tracts have made experiments in agroecology very difficult to execute successfully. When neighbouring large farmers spray voluminous amounts of pesticides from an airplane, the chemical 'drift' undoes Fundo members' efforts to distance themselves from the use of agrochemicals. This makes their efforts to adopt sustainable practices, already restricted by lack of the appropriate supplies and incomplete support, seem essentially futile, and negatively impacts their productive initiatives (interview, 8 August 2012). In sum, when inadequate support for agro-ecological initiatives at both the agency level and the level of coordination between agencies is combined with the challenges that Fundo Zamorano members face due to the persistence of large private farms that continue to employ conventional practices, even idealistic members are reluctant to adopt sustainable practices.

\section{FROM FOOD SOVEREIGNTY TO A NATIONALIST FOOD POLICY}

Venezuela continues to rely heavily on imported food (see Table 1; see also Hernández 2010; Gutiérrez Socorro 2013). On the domestic front, attaining food sovereignty - which, as noted above, we are defining as production by small- and medium-sized farmers of culturally relevant agricultural goods sufficient to feed the population, as the Venezuelan state has defined the term and as the term is commonly used - has remained beyond reach. As a result, the state has initiated a transition to a nationalist food security policy, which has meant pursuing domestic production by any means necessary. This has been manifest in the state's continued laissez-faire attitude towards most large producers, support of small and 
reformed-sector farmers, and, especially, in the growing number of state farms and agricultural goods-processing facilities.

The government has not fundamentally transformed the landholding structure in Portuguesa. As noted above, it has generally not expropriated productive land (see also Table 3). Moreover, the state has begun to supply large producers with subsidized agrochemicals through its agro-input supplier, AgroPatria. With the exception of INTI, Portuguesa's large producers appear to have amicable relations with the agencies under the state's Ministry of Agriculture. The Ministry even adjusts prices for these producers when their harvests fall short of their expectations, according to a representative from one of Portuguesa's largeproducer organizations (interview, 14 August 2012). At the same time, some peasants argue that the state has not done enough to make land available to them, and that many either have plots that are too small and/or have to work for large landholders (interview, 31 July 2013). One reason why the state has allowed most of the property to remain in the hands of large growers in Portuguesa, and has chosen to accommodate them, is that they have continued to contribute the great majority of domestically-oriented agricultural goods.

Meanwhile, as of 2005 the state began to establish Socialist Production Units (UPSs). In agriculture, these took the form of state farms, which were established on expropriated estates. By 2010, the state preferred to set up state farms after expropriating highly-developed private farms, rather than to establish additional Fundos Zamoranos or to give the land to small- and/or medium-sized individual, family or cooperative farmers (see e.g. Enríquez 2013). In Portuguesa, the more advanced technologies employed on, and fertility of, the lands of these farms contrasted sharply with the vast tracts of abandoned, fallow land that were the basis of most of the Fundos Zamoranos. These state farms practiced conventional agriculture, and their workers were wage labourers whose pay was set irrespective of productivity and profitability (interview with UPS representative, 13 August 2012).$^{48}$ In addition to UPS farms, the state has constructed numerous UPS processing plants for agricultural goods. These plants served both producers - by bringing the processing of their produce closer to the farm, and consumers - by directing the processed goods to the state distribution system, which then offered them at subsidized prices. ${ }^{49}$ Also, the UPS farms often assisted the small farmers in the surrounding area in diverse ways (interview, UPS Director, 13 August 2012).

We see the emphasis as of 2010 on forming UPSs on expropriated land as constituting a departure from the state's prior agenda of pursuing food sovereignty, which was based on cooperatives and Fundos Zamoranos. ${ }^{50}$ However, Kappeler (2013) argues that scholars, activists and policy-makers may need to rethink the definition of 'food sovereignty'. He asserts that its pursuit based on the production of small- and medium-sized farmers, including cooperatives and Fundos - which has been the Venezuelan state's expressed strategy - may not be realistic in a country with such a notably-urbanized population. There simply may not be enough

\footnotetext{
48 The state has expropriated the several farms that have been converted into agricultural UPSs in Portuguesa for various reasons, among which have been allegations that former owners were involved in drug trafficking. Regardless of the particular reasons, such expropriations have provided the state with highly capitalized farms. UPS workers do exercise a degree of control over such enterprises through their workers' councils. For a discussion of non-agricultural UPSs and the variation among them in decision-making authority, see Azzellini (2011) and Larrabure (2010). These enterprises are known variously as Unidades de Producción Socialista, Unidades de Propiedad Social (see e.g. Aló Presidente 378, 29 January 2012), sometimes Unidades Productivas de Propiedad Social and even 'joint enterprises'.

49 One such plant visited by one of the authors provided free milk daily to 5,000 school children in its vicinity (interview, 26 July 2012).

50 It remains possible, though, that Venezuela's latest state-society transformation initiative - the establishment of a new, commune-based geopolitical-economic configuration - may eventually re-enthrone the principle of food sovereignty.
} 
Table 4. A summary of the argument

\begin{tabular}{llcc}
\hline Agent(s) & Factor & Mechanism & Outcome \\
\hline \multirow{2}{*}{ State } & Lack of agency-level capacity & $\begin{array}{c}\text { Agencies unable to carry out } \\
\text { initiatives }\end{array}$ & $\begin{array}{c}\text { Reorientation of } \\
\text { political-economic agenda } \\
\text { (from food sovereignty to } \\
\text { food security) }\end{array}$ \\
\cline { 2 - 4 } & $\begin{array}{c}\text { Contradictory inter-agency } \\
\text { division of labour }\end{array}$ & $\begin{array}{c}\text { Nullification of some agency } \\
\text { initiatives }\end{array}$ & Undercuts change-oriented \\
Farmers & $\begin{array}{c}\text { Persistence of old property } \\
\text { structure }\end{array}$ & $\begin{array}{c}\text { Undignation to shift in } \\
\text { practices }\end{array}$ & political-economic agenda \\
\hline
\end{tabular}

such farmers to feed urban dwellers there. Therefore, it may be necessary to combine the efforts of various types of small- and medium-sized production with those of the state, as embodied in the UPSs, as the Venezuelan government has done. Kappeler (2013, 14), thus, defines food sovereignty as 'the right of nations to self-determination'. Nonetheless, in pointing to the shift from a food sovereignty agenda to one of nationalist food security, we have chosen to rely upon the definition most commonly utilized in the literature on this topic. ${ }^{51}$

\section{CONCLUSION}

Venezuela's abundant resources have provided the state with an opportunity to effect a peaceful political-economic transformation. Those resources have, in principle, given the Venezuelan state a means of circumventing the incompatibility between radical government goals and the persistence of the elite's political-economic power (cf. Przeworski 1991). The state can fund the kind of initiatives it wishes to pursue, and largely leave the old elite alone. However, the state's ability to accomplish a crucial change-oriented project - attaining food sovereignty - has been partial at best. In our examination of Portuguesa's Fundos Zamoranos, we have identified three primary reasons for this: with regard to the organization of the state, a lack of agency-level capacity to adequately carry out such a transformation, and inter-agency conflict, in which agencies' pursuits contradict and sometimes nullify one another; and, with regard to farmers, the absence of a thoroughgoing alteration of the agrarian property structure, which has relegated the food-sovereignty initiative to the least productive land, and has made adoption of sustainable practices seemingly futile to reform-oriented producers (see Table 4).

Although the Chávez (and now Maduro) government has attempted to push the process of development along a new path, the regime came to power via elections and has retained its electoral orientation. Thus, el proceso did not 'smash the state', as was the case in most similar radical social transformations. Instead, the government has reformed numerous existing agencies and established a number of others in order to build the institutional structure necessary to pursue an agenda distinct from that of the pre-1999 governments. Building this transformation-oriented institutional structure parallel to the extant structures meant establishing a bifurcated institutional arrangement similar to what Lenin (1975a [1917]) and Trotsky (1957 [1932]) referred to as 'dual power'. Yet, whereas for them 'dual power' is a momentary

51 See footnote 23 above.

(C) 2015 John Wiley \& Sons Ltd 
phase in the process of change, Venezuela's dual-institutional structure constitutes a prolongation of this tension-ridden state of affairs. Consequently, inter-agency conflicts have emerged and have had important implications. Jessop (1982) argues that the state institution acts on behalf of the interests of dominant and dominated classes, as expressed in distinct forms of state intervention. The Venezuelan state does intervene on behalf of both dominant and dominated classes. Nonetheless, promoting contradictory interests begs the question of what agenda will prevail, and why. Poulantzas (1978) argues that the capitalist state coordinates the disparate fractions of the dominant class - and therefore harbours internal contradictions that determine state policy goals - and disorganizes the dominated class. However, in the case of the dual-institutional state, the question is more complex. First, it has to do with: (i) the degree to which the state positively coordinates agencies that further the interests of disparate fractions of the dominant classes; and (ii) how successfully the state coordinates the group of agencies that further the interests of the disparate fractions of the dominated classes. Second, it has to do with: (iii) how each group of agencies - that is, the capacity of each side of the dual-institutional state - compares with the other; and (iv) whether the state has upheld, or made sufficient inroads into, private property to enhance state capacity dedicated to the fractions of the dominant classes or the dominated ones. Since the state sets specific goals for itself and constantly acts on behalf of both the hitherto dominant and dominated classes, we have analysed how its interventions have measured up to one of its goals: food sovereignty. ${ }^{52}$

In Portuguesa, the Venezuelan state has most often intervened to uphold the interests of portions of the agrarian elite, and el proceso did not break with this. But the state has done a lot for the Venezuelan peasantry and committed many resources to affect a transition to food sovereignty. Yet, in our analyses of credit timeliness, purchasing and marketing of crops, and purveying inputs, we found that the Fundos Zamoranos suffered from agencies that lacked sufficient capacity to support them. Moreover, we found contradictions in the division of labour between state agencies, as was the case with INTI and state crediting agencies, and between FONDAS and CIARA, which undermined sustainable farming efforts. Thus, in Portuguesa, the capacity of the transformation-oriented institutional structure has not surpassed that dedicated to the status quo with respect to food sovereignty. Meanwhile, the state has not made sufficient inroads against extant private property to tip the scales away from large growers and in favour of initiating a transition to food sovereignty, so as to compensate for the relative lack of capacity of the institutional structure consistent with such ends. The Fundos' relatively-limited contribution to national food-crop production has been the end result of these contradictions. And, in turn, this outcome has been an impetus for the state to shift its 'substantive support' - the 'allocation of particular conditions of production to particular economic agents' (Jessop 1982, 234) - from food sovereignty towards food security, which is manifest in the formation of state farms. These farms, which were not part of the state's initial agrarian transformation agenda, have been established amidst the Fundos Zamoranos, small and medium farmers in and out of the reformed sector and large farmers. Together, this array of farms populates the countryside in Portuguesa. The increasing numbers of state farms,

52 Elements of the tension between ongoing state activities and novel socialist state initiatives have existed in other, more rapid, transformations towards socialism. Late in his life, Lenin even noted that the state had not really been smashed and fully eliminated during the Russian Revolution: 'the [state] apparatus we call ours is, in fact, still quite alien to us; it is a bourgeois and tsarist hotch-potch and there has been no possibility of getting rid of it in the course of the past five years without the help of other countries and because we have been "busy" most of the time with military engagements and the fight against famine' (Lenin 1975c [1922], 720). Yet, even if the persistence of such tensions is the rule rather than the exception, it is generally agreed that the Venezuelan state has transitioned towards socialism much more slowly than other cases (which is partially due to the electoral nature of the transformation). 
along with the persistence of the other farms, embody the dual-institutional state's nationalist food-security agenda of production by any means necessary.

The state's inability to execute this development goal and control its agenda is partially attributable to the special importance of food. Thomas' (1974) 'First Iron Law' - wherein states in transition to socialism must ensure national production for population consumption needs - has lived on in Venezuela. The law, which is important for all states that pursue this path, is perhaps even more important for socialist-leaning regimes that come to power through elections and that promote a mixed economy than it is for regimes that initiate socialist change through armed struggle. This is because the landed elite and other parts of the upper classes wield considerable power to influence the availability of food, and because such regimes need to maintain legitimacy - which food shortages can undermine - in the context of periodic electoral contests. The agrarian elite was the key constituent in agrarian policy in the past, and remains essential to it today. Working within these limitations, the state's continued support for and reliance upon private, large-scale agrarian property structures, along with their conventional practices, has restricted its capacity to accomplish its transformative development goals: it has not allowed the state to sufficiently reorient its interventions.

This raises the question of state autonomy. In affecting capitalist development outcomes, Evans (1995) points to the need for both bureaucratic autonomy and within-bureau cohesion. Yet, as Mann (1984) insists, state capacity is premised on an effective division of labour between its various activities. Bringing these two perspectives together, Chibber (2002) shows how inter-agency coordination is the decisive factor in determining the success of state-led development initiatives. But an additional consideration must be introduced when contemplating the Venezuelan case. Though the Venezuelan state resembles the states that Evans and Chibber examine in terms of its high profile in development initiatives, its political-economic ambitions differ from such states in that it seeks social equity in addition to economic diversification and growth. Moreover, the Chavista government has not had the freedom to completely overhaul the state so as to fine-tune it to these objectives. Consequently, the agencies in the reform-oriented institutional structure focused on agriculture have had considerable difficulty coordinating their efforts to serve their constituents - the peasantry. Fox (1992) argues that the peasantry can pressure some parts of the state to accommodate its demands even when facing a somewhat hostile state overall. In Venezuela, due both to an explicit pro-poor agenda and to lack of inter-agency cooperation, such pressure has led some agencies (e.g. INTI) to demand that other agencies (e.g. FONDAS) bend their rules to accommodate peasants' needs in an ad hoc manner. Instead of working together according to a division of labour, these agencies jostle with one another to modify their practices when confronted with popular pressure. While this serves the peasants' needs in the immediate term, such makeshift accommodations are unlikely to persist after these agencies consolidate their bureaucratic structures and procedures.

And not all of the lack of coordination among agencies is so benign. Sometimes, the practices of one agency (e.g. those of FONDAS) directly contradict those of another (e.g. those of CIARA) (cf. Coraggio 1986). These dynamics point to the lack of coherence within the overall state structure with regard to the 'project' that the state is oriented towards which is a logical outcome of its dual-institutional nature.

This configuration also raises the question of whether the potential that Saul (1974) had spoken of - that peasants and workers would lose out as a consequence of struggles within the state over the direction development would take - is coming to fruition in Venezuela today. Clearly, many previously-landless and land-poor peasants now have access to resources they did not have in the past. And some of those resources - such as credit - have only 
become more abundant in recent years. Yet, landlessness remains a problem. The creation of UPSs on expropriated property, especially that which is more developed and fertile, does nothing to redress this issue.

These intra-state dynamics and their effects on the peasantry impact not only the success of the initiatives of the transformation-oriented institutional structure. They also negatively bias assessment of the viability of the goals themselves. Thus, in the context of ongoing adjustment of development policy, these circumstances have contributed to the central state's evident gradual shift over the past several years from a radical project of food sovereignty to a nationalist food-security orientation that aims to augment production but not necessarily to fundamentally transform agrarian practices or the rural class structure. The nationalist orientation relies upon the continued use of conventional, petrochemical-based production practices. It also entails the persistence of the old property structure, alongside Fundos Zamoranos and other reformed farms, and a smattering of Socialist Production Units (UPSs), or state farms.

Some potentially generalizable lessons can be drawn from the foregoing. The national state's inability to attain food sovereignty and - in the context of lack of agency-level capacity, inter-agency conflict and the persistence of the old property structure - its shift to a goal of nationalist food security, suggests that even best-case-scenario, electoral-socialist states that do not thoroughly reconfigure their state structures will have trouble accomplishing their goals. With respect to such states' radical development goals, both the institutional structure dedicated to transformation (which is partially a function of inter-agency coordination) and alteration of the property structure appear to be crucial. States may need to remain autonomous from powerful elite groups and popular sectors alike to affect a course of developmentalist political-economic change (cf. Evans 1995). Yet, in order to play an effective role in radical development, the state may need to deprive old elites of support while bolstering institutional capacity - agency-level capacity and inter-agency coordination - dedicated to the sectors central to the new goals. The extent to which this is possible under an electoral state that does not make significant inroads into private property appears, based on this case study, to be limited.

\section{REFERENCES}

Abrams, P., 1988. 'Notes on the Difficulty of Studying the State'. Journal of Historical Sociology, 1: 58-89.

Alavi, H., 1972. 'The State in Post-Colonial Societies: Pakistan and Bangladesh'. New Left Review, (74): 59-81.

Altieri, M.A., 1995. Agroecology: The Science of Sustainable Agriculture. Boulder, CO: Westview Press.

Altieri, M.A. and C.I. Nicholls, 2002. 'Una perspectiva agroecológica para una agricultura ambientalmente sana y socialmente más justa en la América Latina del Siglo XXI'. In La transición hacia el desarrollo sustentable en América Latina y el Caribe, eds. E. Leff, E. Ezcurra, I. Pisanty and P. Romero Lankao, 281-304. Mexico City: Instituto Nacional de Ecología, Universidad Autónoma Metropolitana and Programa de Naciones Unidas para el Medio Ambiente.

Altieri, M.A. and V.M. Toledo, 2011. 'The Agroecological Revolution in Latin America: Rescuing Nature, Ensuring Food Sovereignty and Empowering Peasants'. Journal of Peasant Studies, 38 (3): 587-612.

Amsden, A.H., 2001. The Rise of 'the Rest': Challenges to the West from Late-Industrializing Economies. Oxford: Oxford University Press.

Arráiz, L.E., 2014. 'Incautaron mil toneladas de alimentos en la frontera'. El Universal, 13 August.

Azzellini, D., 2011. 'De las cooperativas a las Empresas de Propiedad Social Directa en el proceso venezolano'. In Cooperativas y socialismo: una mirada desde Cuba, ed. C. Piñiero-Harnecker, 301-20. Havana: Editorial Caminos.

Badgley, C., J. Moghtader, E. Quintero, E. Zakem, M.J. Chappell, K. Aviles-Vazquez, A. Samulon and I. Perfecto, 2007. 'Organic Agriculture and the Global Food Supply'. Renewable Agriculture and Food Systems, 22 (2): 86-108.

Beasley-Murray, J., M.A. Cameron and E. Hershberg, 2010. 'Latin America's Left Turns: A Tour d'Horizon'. In Latin America's Left Turns: Politics, Policies and Trajectories of Change, eds. M.A. Cameron and E. Hershberg, 1-20. Boulder, CO: Lynne Rienner. 
Borón, A., 2008. Socialismo siglo XXI: ¿Hay vida después del neoliberalismo? Buenos Aires: Ediciones Luxemburg.

Buxton, J., 2003. 'Economic Policy and the Rise of Hugo Chávez'. In Venezuelan Politics in the Chávez Era: Class, Polarization and Conflict, eds. S. Ellner and D. Hellinger, 113-30. Boulder, CO: Lynne Rienner.

Cannon, B., 2009. Hugo Chávez and the Bolivarian Revolution: Populism and Democracy in a Globalised Age. Manchester: Manchester University Press.

Chibber, V., 2002. 'Bureaucratic Rationality and the Developmental State'. American Journal of Sociology, 107 (4): 951-89.

CIAAL (Centro de Investigaciones Agroalimentarias), 2011. 'Tema 2: elementos resaltantes de los resultados del VII Censo Agrícola Nacional 2007-2008’. July, http://www.saber.ula.ve/handle/123456789/33534 (accessed 10 December 2014).

Ciccariello-Maher, G., 2007. 'Dual Power in the Venezuelan Revolution'. Monthly Review, 59 (4): 42-56.

Coraggio, J.L., 1986. 'Economics and Politics in the Transition to Socialism: Reflections on the Nicaraguan Experience'. In Transition and Development: Problems of Third World Socialism, eds. R.R. Fagen, C.D. Deere and J.L. Coraggio, 143-70. New York: Monthly Review Press.

Coronil, F., 1997. The Magical State: Nature, Money and Modernity in Venezuela. Chicago, IL: University of Chicago Press.

Coronil, F, 2011. 'State Reflections: The 2002 Coup against Hugo Chávez'. In The Revolution in Venezuela: Social and Political Change under Chávez, eds. T. Ponniah and J. Eastwood, 37-65. Cambridge, MA: Harvard University David Rockefeller Center for Latin American Studies.

Corrigan, P.R.D. and D. Sayer, 1985. The Great Arch: English State Formation as Cultural Revolution. Oxford: Blackwell.

Da Corte, M.L., 2014. “"El estado no puede asumirlo todo”: entrevista Alí Rodríguez Araque, secretario general saliente de la Unión de Naciones Suramericanas (UNASUR)', El Universal (Caracas), 10 August.

De Cordoba, J., 2007. 'Land Grab: Farms are Latest Target in Venezuelan Upheaval'. The Wall Street Journal, 17 May.

Delahaye, O., 2001. Políticas de tierras de Venezuela en el siglo XX. Caracas: Fondo Editorial Tropykos.

Delahaye, O., 2008. 'La cuestión agraria en los últimos años: ¿Más de lo mismo?’ SIC, 703 (April): 104-9.

Di John, J., 2009. From Windfall to Curse: Oil and Industrialization in Venezuela from 1920 to the Present. Pennsylvania, PA: Pennsylvania State University Press.

Ellner, S., 2008. Rethinking Venezuelan Politics: Class, Conflict and the Chávez Phenomenon. Boulder, CO: Lynne Rienner.

Ellner, S., 2013. 'Social and Political Diversity and the Democratic Road to Change in Venezuela'. Latin American Perspectives, 40 (3): 63-82.

Enríquez, L.J., 2013. 'The Paradoxes of Latin America's "Pink Tide”: Venezuela and the Project of Agrarian Reform'. Journal of Peasant Studies, 40 (4): 611-38.

Evans, P. and J.E. Rauch, 1999. "Bureaucracy and Growth: A Cross-National Analysis of the Effects of "Weberian" State Structures on Economic Growth'. American Sociological Review, 64 (5): 748-65.

Evans, P.B., 1995. Embedded Autonomy: States and Industrial Transformation. Princeton, NJ: Princeton University Press.

Evans, P.B. and D. Rueschemeyer, 1985. 'The State and Economic Transformation: Toward an Analysis of the Conditions Underlying Effective Intervention'. In Bringing the State Back In, eds. P.B. Evans, D. Rueschemeyer and T. Skocpol, 44-77. Cambridge, UK: Cambridge University Press.

Evans, P.B., D. Rueschemeyer and T. Skocpol, 1985. 'On the Road toward a More Adequate Understanding of the State'. In Bringing the State Back In, eds. P.B. Evans, D. Rueschemeyer and T. Skocpol, 347-66. Cambridge, UK: Cambridge University Press.

Fagen, R.R., C.D. Deere and J.L. Coraggio, eds., 1986. Transition and Development: Problems of Third World Socialism. New York: Monthly Review Press.

Fernandes, S., 2010. Who Can Stop the Drums? Urban Social Movements in Chávez's Venezuela. Durham, NC: Duke University Press.

Figueroa, R., 1990. La agroindustria subordina al campo venezolano. Caracas, Venezuela: Centro de Documentación e Investigación Regional-Portuguesa, Academia Nacional de Ciencias Económicas.

FONDAS (Fondo para el Desarrollo Agrario Socialista), 2011. 'Informe balance de gestión FONDAS-Portuguesa "Misión AgroVenezuela 2011-2012", Unpublished report.

Fox, J., 1992. The Politics of Food in Mexico: State Power and Social Mobilization. Ithaca, NY: Cornell University Press. Gunson, P., 2006. 'Corruption Alleged in Farm Credit Program'. The Miami Herald, 3 August.

Gutiérrez Socorro, A., 2013. 'Venezuela: Renta petrolera, socialismo del siglo XXI y comercio exterior agroalimentario'. Paper presented at the conference entitled 'Comercio agrícola y América Latina. Cuestiones, controversias y perspectivas’, at FLACSO, Buenos Aires, 19-20 September. 
Haslam, P.A., 2010. 'Foreign Investors over a Barrel: Nationalizations and Investment Policy'. In Latin America's Left Turns: Politics, Policies and Trajectories of Change, eds. M.A. Cameron and E. Hershberg, 209-30. Boulder, CO: Lynne Rienner.

Hernández, J.L., 2010. 'La agricultura en Venezuela'. Temas de Formación Sociopolítica, (12-13): 1-219.

INE (Instituto Nacional de Estadística), 2014. 'Informe comparativo semestral, "encuesta de hogares por muestreo" pincipales indicadores de la fuerza de trabajo, entidad: Portuguesa. Primer semestre 2011 - primer semestre 2013', http://www.ine.gov.ve/index.php?option=com_content\&view=category\&id=103\&Itemid=40\# (accessed 17 April 2015).

Kappeler, A., 2013. 'Perils of Peasant Populism: Why Redistributive Land Reform and “Food Sovereignty" Can't Feed Venezuela'. Conference Paper \#65, 'Food Sovereignty: A Critical Dialogue' International Conference, Yale University, 14-15 September.

Karl, T.L., 1997. The Paradox of Plenty: Oil Booms and Petro-States. Berkeley, CA: University of California Press.

Jessop, B., 1982. The Capitalist State: Marxist Theories and Methods. New York: New York University Press.

Joseph, G.M. and D. Nugent, eds., 1994. Everyday Forms of State Formation: Revolution and the Negotiation of Rule in Modern Mexico. Durham, NC: Duke University Press.

Larrabure, M., 2010. 'Praxis, Learning and New Cooperativism in Venezuela: An Initial Look at Venezuela's Socialist Production Units'. Affinities: A Journal of Radical Theory, Culture and Action, 4 (1): 288-309.

Lenin, V.I., 1975a [1917]. 'April Theses'. In The Lenin Anthology, ed R.C. Tucker, 295-300. New York: Norton.

Lenin, V.I., 1975b [1917]. 'The Dual Power'. In The Lenin Anthology, ed R.C. Tucker, 301-4. New York: Norton.

Lenin, V.I., 1975c [1922]. 'The Question of Nationalities or “Autonomisation”'. In The Lenin Anthology, ed R.C. Tucker, 719-24. New York: Norton.

Mahdavy, H., 1970. 'Patterns and Problems of Economic Development in Rentier States: The Case of Iran'. In Studies in the Economic History of the Middle East, ed M. Cook, 428-67. Oxford: Oxford University Press.

Mann, M., 1984. 'The Autonomous Power of the State: Its Origins, Mechanisms and Results'. Archives européennes de sociologie, 25: 185-213.

MPPAT (Ministerio del Poder Popular para la Agricultura y Tierras), 2008. VII Censo Agrícola, http://censo.mat .gob.ve/ (accessed 10 December 2014).

Nardelli, A., L. Elliott, A. Luhn, S.K. Dehghan, I. Black and V. Lopez, 2014. 'Recession in Russia, Revolt in Venezuela? The Knock-on Effects of Tumbling Oil Prices. The Guardian, 16 October.

Nelson, M., 2013. 'Institutional Conflict and the Bolivarian Revolution: Venezuela's Negotiation of the Free Trade Area of the Americas'. Latin American Perspectives, 40 (3): 169-83.

Page, T.L., 2011. The Ambiguous Transition: Building State Capacity and Expanding Popular Participation in Venezuela's Agrarian Reform. Ph.D. dissertation, University of California, Berkeley.

Patel, R., 2009. 'Food Sovereignty'. Journal of Peasant Studies, 36 (3): 663-706.

Poulantzas, N., 1969. 'The Problem of the Capitalist State'. New Left Review, (58): 67-78.

Poulantzas, N., 1973. Political Power and Social Classes, trans. T. O’Hagan. London: NLB and Sheed and Ward.

Poulantzas, N., 1978. State, Power, Socialism, trans. P. Camiller. London: Verso.

PROVEA (Programa Venezolano de Educación-Acción en Derechos Humanos), 2013. Situación de los derechos humanos en Venezuela: informe anual enero-diciembre 2013. Caracas: PROVEA.

Przeworski, A., 1991. 'Could We Feed Everyone? The Irrationality of Capitalism and the Infeasibility of Socialism'. Politics \& Society, 19 (1): 1-69.

Purcell, T.F., 2013. 'The Political Economy of Social Production Companies in Venezuela'. Latin American Perspectives, 40 (3): 146-68.

República Bolivariana de Venezuela, 1999. 'Constitución de la República Bolivariana de Venezuela'. Gaceta Oficial, Caracas, 30 December.

República Bolivariana de Venezuela, 2008. 'Ley Orgánica de Seguridad y Soberanía Agroalimentaria’. Gaceta Oficial, 31 July.

República Bolivariana de Venezuela, 2013. Ministerio del Poder Popular para la Agricultura y Tierras: memoria 2013. Caracas: República Bolivariana de Venezuela, http://transparencia.org.ve/que-hacemos/monitoreo-a-lacorrupcion/memoria-y-cuenta-de-instituciones-publicas/ (accessed 14 January 2015).

Ríos, J. and G. Carvallo, 1990. Análisis histórico de la organización del espacio en Venezuela. Caracas: Universidad Central de Venzuela.

Roberts, K., 2003. 'Social Polarization and the Populist Resurgence in Venezuela'. In Venezuelan Politics in the Chávez Era: Class, Polarization and Conflict, eds. S. Ellner and D. Hellinger, 55-72. Boulder, CO: Lynne Rienner.

Roberts, K., 2006. 'Populism, Political Conflict and Grass-Roots Organization in Latin America'. Comparative Politics, 38 (2): 127-48. 
Rockefeller, S.A., 2007. 'Dual Power in Bolivia: Movement and Government since the Election of 2005'. Urban Anthropology and Studies of Cultural Systems and World Economic Development, 36 (3): 161-93.

Saul, J.S., 1974. 'The State in Post-Colonial Societies: Tanzania'. Socialist Register, 11 (11): 349-72.

Schiller, N., 2011. 'Catia Sees You: Community Television, Clientelism and the State in the Chávez Era'. In Venezuela's Bolivarian Democracy: Participation, Politics and Culture under Chávez, eds. D. Smilde and D. Hellinger, 104-31. Durham, NC: Duke University Press.

Thomas, C.Y., 1974. Dependence and Transformation: The Economics of the Transition to Socialism. New York: Monthly Review Press.

Tilly, C., 1973. 'Does Modernization Breed Revolution?' Comparative Politics, 5 (3): 425-47.

Trotsky, L., 1957 [1932]. The History of the Russian Revolution. Ann Arbor, MI: University of Michigan Press.

Weisbrot, M. and J. Johnston, 2012. 'Venezuela's Economic Recovery: Is It Sustainable?' Center for Economic and Policy Research, Unpublished report.

Wittman, H., 2011. 'Food Sovereignty: A New Rights Framework for Food and Nature?' Environment and Society: Advances in Research, 2: 87-105.

Wolford, W., 2010. 'Participatory Democracy by Default: Land Reform, Social Movements and the State in Brazil'. Journal of Peasant Studies, 37 (1): 91-109.

Yates, D.A., 1996. The Rentier State in Africa: Oil Rent Dependency and Neocolonialism in the Republic of Gabon. Trenton, NJ: Africa World Press.

\section{APPENDIX A: GLOSSARY OF ACRONYMS}

BAV
CIARA
FONDAFA
FONDAS
GMAV
INDER
INIA
INSAI
INTI
MPPAT
PDVSA
UPS

Agricultural Bank of Venezuela

Foundation for Training and Innovation for Rural Development

Development Fund for Agriculture, Fishing, Forestry and Related Activities Development Fund for Socialist Agriculture

Gran Misión AgroVenezuela

Rural Development Institute

National Institute of Agricultural Research

National Institute of Integral Agricultural Health

National Land Institute

Ministry of Popular Power for Agriculture and Land

Venezuelan Oil Co.

Socialist Production Unit

\section{APPENDIX B}

The Venezuelan central state has sought to augment domestic agricultural production nationwide, but has had limited success. Our geographical focus, the State of Portuguesa, has been central to Venezuela's domestic food-crop production. As Figure B1 shows, after some promising growth in the late 2000s, total domestic rice production in 2010 and 2011 approximated what it was in the late 1990s and early 2000s. Portuguesa consistently contributed about half of domestic rice production for the entire period from 1995 to 2011. As Figure B2 shows, domestic corn production has generally increased during the past decade, particularly after 2003. But since 2009, production levels have varied greatly. Portuguesa contributed between a third and half of domestic production between 1995 and 2011. Finally, domestic sorghum production has remained relatively constant, as Figure B3 shows. However, Portuguesa's contribution to domestic production has varied greatly between 1995 and 2011, ranging from almost half to less than one eighth. 
Figure B1 Rice production in Venezuela and in Portuguesa, 1995-2011

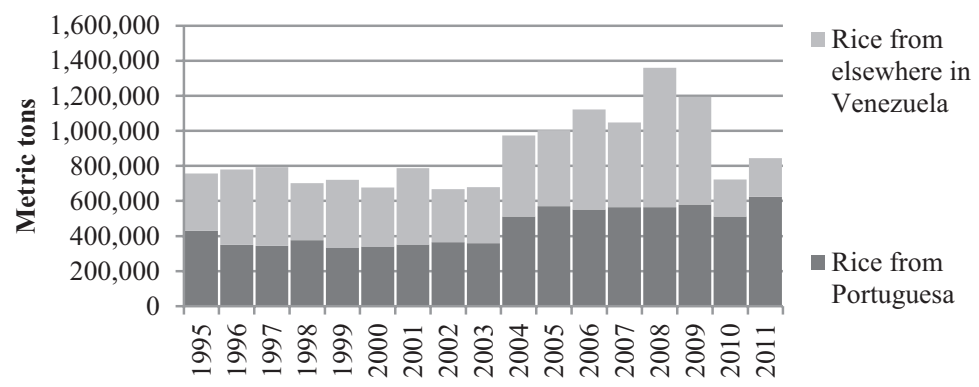

Source: FEDEAGRO, http://www.fedeagro.org/produccion/Rubros.asp (accessed 6 January 2013); unpublished data from MPPAT Portuguesa.

Figure B2 Corn production in Venezuela and in Portuguesa, 1995-2011
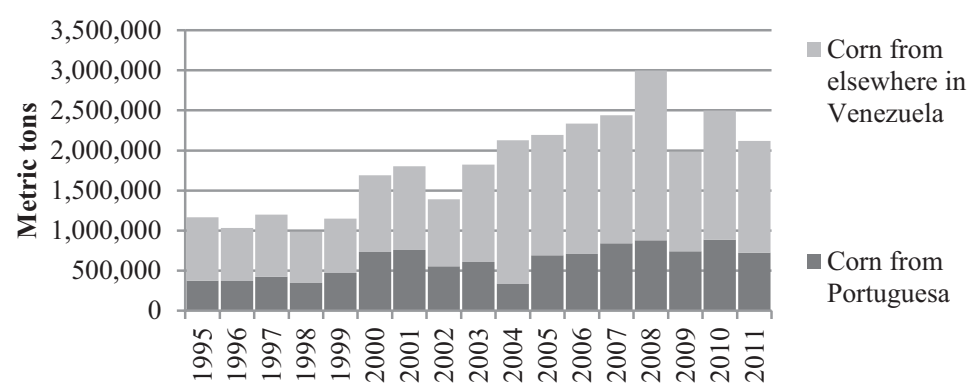

Source: FEDEAGRO, http://www.fedeagro.org/produccion/Rubros.asp (accessed 6 January 2013); unpublished data from MPPAT Portuguesa.

Figure B3 Sorghum production in Venezuela and in Portuguesa, 1995-2011

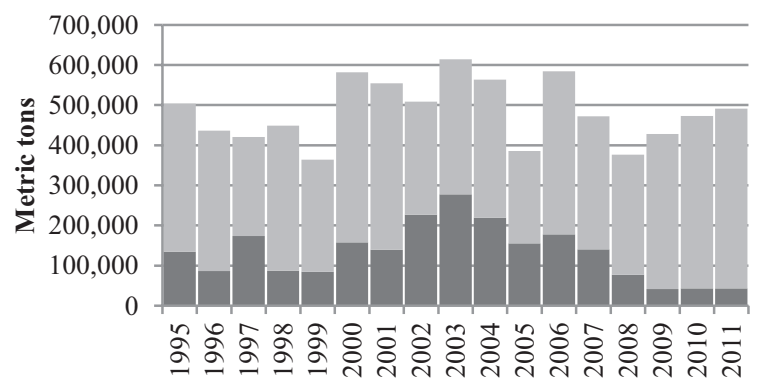

Sorghum from elsewhere in

Venezuela

- Sorghum from

Portuguesa

Source: FEDEAGRO, http://www.fedeagro.org/produccion/Rubros.asp (accessed 6 January 2013); unpublished data from MPPAT Portuguesa. 


\section{APPENDIX C}

Table C1 presents the number of employees of select state agencies, according to category of employment. The reader should note that these figures are summations of numbers of employees of all the state-specific divisions of the agencies in question (i.e. they are not only for Portuguesa).

Table C1. Number of employees in selected state agencies, nationwide, 2013

\begin{tabular}{lrcrrrr}
\hline Agency & Directors & $\begin{array}{c}\text { Professionals } \\
\text { and technicians }\end{array}$ & Administrators & Workers & $\begin{array}{c}\text { Contract } \\
\text { workers }\end{array}$ & Total \\
\hline BAV & 24 & 688 & 76 & 93 & 359 & 552 \\
CIARA & 61 & 605 & 491 & 0 & 0 & 1,157 \\
FONDAS & 234 & 2,155 & 287 & 375 & 2,442 & 338 \\
INDER & 51 & 62 & 15 & 76 & 723 & 865 \\
INIA & 163 & 1,062 & 145 & 1,369 & 738 & 2,415 \\
INSAI & 12 & 281 & 108 & 605 & 1,744 & 2,469 \\
INTI & 511 & 968 & 350 & 449 & 1,150 & 2,460 \\
\hline
\end{tabular}

Source: República Bolivariana de Venezuela $(2013,580,751,760,790,857,871,887)$. 